\title{
6. \\ In the Guise of Gods and Heroes: Portrait Heads on Roman Mythological Sarcophagi
}

\author{
Zahra Newby
}

The Roman practice of adding portrait heads to the characters on mythological sarcophagi is well known. These faces with their individualised features and period hairstyles gaze out at us from the pages of handbooks and catalogues, giving a vivid impression of the way that Roman lives and deaths could be directly equated with the fates of mythological figures. Yet this very ubiquity begs a question: just how representative of the larger category of Roman mythological sarcophagi are the chests with portrait heads? The aim of this paper is to conduct a close analysis of mythological sarcophagi with portrait heads, to look at what the presence of portraits adds to the mythological scenes and to ask whether they should be seen as simply intensifying the message of a mythological scene or of altering and nuancing it in a particular way.

Despite the familiarity of sarcophagi with portrait heads, little analysis of these chests as a group has been done. ${ }^{1}$ While readings of some individual pieces suggest that the addition of portrait heads sometimes refocused the meaning of a myth in surprising ways, the prevailing assumption among scholars seems to be that portrait features on sarcophagi merely reinforce the normal message of the mythological subject matter. ${ }^{2}$ For many scholars, the portraits simply make explicit a message which may be more muted elsewhere. In Koortbojian's words 'all mythological sarcophagi assert analogies; the presence of the portrait features of the deceased merely intensifies and particularizes the monument's message'. ${ }^{3}$

Greater analysis of the sarcophagi with portrait heads might be expected from Henning Wrede's discussion of images assimilating individuals with particular gods. This discusses a number of mythological sarcophagi alongside statues or reliefs which show individuals in the dress of, or with the attributes of, divine figures. ${ }^{4}$ However, Wrede's focus is necessarily selective, and depends on

1 For brief accounts see Fittschen 1970, 188, n. 64 f.; Schauenburg 1980, esp. 153-4; Koch-Sichtermann 1982, 607-14; Zanker and Ewald 2004, 45-50. On unfinished heads see also Andreae 1984 and Huskinson 1998.

2 Individual accounts: Blome 1992, 1062-5; Zanker 1999. Fittschen 1984 concentrates on the portraits as evidence for dating but also reveals a few unusual uses of the myths.

3 Koortbojian 1995, 18.

4 Wrede 1981, esp. 139-57. 
his own reading of the meaning of the myths. Apart from scenes showing the deceased in the guise of a particular god (relatively rare on sarcophagi except in the cases of Selene and Mars), Wrede only includes mythological sarcophagi showing heroes when he reads the myth as one of apotheosis. ${ }^{5}$ Rather than analysing what the addition of portrait heads adds to these sarcophagi, Wrede starts from the belief that they show prospective messages about a happy afterlife and does not examine how sarcophagi with portrait heads differ from those without. $^{6}$

The messages of mythological imagery on sarcophagi have, however, been extensively debated for decades with views ranging from those which see the myths as allegories of apotheosis, expressing belief in the soul's continued survival after death, to interpretations of them as retrospective, commenting on the deceased's qualities and interests during life, or simply reflecting his tastes and education. ${ }^{7}$ Recent scholarship stresses the multiple levels at which mythological sarcophagi could be interpreted, adding to the ranks of interpreters bereaved relatives seeking consolation for the sudden death of a loved-one, or the ante-mortem purchaser commissioning his or her own tomb. ${ }^{8}$ Interpretations of the meaning of portraits on particular mythological figures often seem simply to reflect an individual scholar's view of what that particular myth meant in a funerary context. ${ }^{9}$ Yet study of funerary inscriptions suggests a wide range of views about life and death, ranging from the bleak to the hopeful, suggesting that belief in immortality was, as Lattimore concluded, 'not widespread, nor clear, nor very strong. ${ }^{10}$ While some representations of myths were more violent, or conversely more idyllic, than others, the same imagery could in some circumstances provoke differing interpretations depending on the beliefs and hopes of those who viewed it. Close examination of some individual sarcophagi with portrait faces leads me to challenge the dominant assumption that they simply intensify the normative message of the mythological subject matter and, indeed, that one dominant reading of a myth always existed. Rather,

5 Wrede 1981, 5-6. Ariadne is included, Endymion not. For criticism of the subjective criteria applied, see Mottahedeh 1984.

6 Wrede 1981, 168-75.

7 The poles of the argument are represented by Cumont 1942 and Nock 1946, with modifications by other scholars. For discussion see Turcan 1978; Koch-Sichtermann 1982, 583-617; also Müller 1994, 139-70. The reviews by North 1983, Grassinger 1998, Ewald 1999 also comment on interpretation.

8 Zanker and Ewald 2004 especially stress the messages to the bereaved, sometimes underplaying the role of those who commissioned their tombs before death. For the importance of organising one's tomb during life see Trimalchio in Petronius, Satyricon 71 discussed by Whitehead 1993 .

9 E.g. Engemann 1973, 28 on the self-evident interpretation of Ariadne and Endymion as symbols of apotheosis.

10 Lattimore $1942,342$. 
I will argue that the addition of portrait features reflects an awareness of the multivalency of mythological imagery and the desire to authorise a particular interpretation of the myth, changing and particularising its meaning in interesting and important ways.

\section{The frequency and distribution of portrait heads}

Despite the frequency with which mythological sarcophagi with portrait heads are illustrated, they are not actually that common. Of around 1200 mythological sarcophagi of Roman production which survive, only about 70 include either portrait features or unfinished heads. Even taking into account the fact that a large proportion of the surviving sarcophagi are too fragmentary or damaged to tell whether portraits were originally present, this is a very small proportion. The distribution of portraits across different myths is also uneven, as can be seen in Table $1 .{ }^{11}$

While the small numbers involved mean that the statistics should be handled carefully, some features are immediately apparent. Firstly, a large number of mythological scenes never include portrait heads. ${ }^{12}$ These include violent scenes such as the deaths of the Niobids and the abduction of the daughters of Leucippus, as well as scenes often taken to refer to the virtus of the deceased, such as Achilles on Scyros. On other myths, portrait heads are definitely the exception rather than the rule. This is especially true for the sarcophagi with the rape of Persephone and those showing Meleager, two of the most popular themes on sarcophagi but with very few examples of portrait heads. In other myths, portrait features are much more popular, as on sarcophagi showing Achilles and Penthesilea, or Mars approaching the sleeping Rhea Silvia. This last group of sarcophagi is a small one, and only emerges in the third century. It is, however, closely related to the scenes of Selene approaching the sleeping Endymion and Dionysus's discovery of the sleeping Ariadne. Both

11 The numbers here are based on the catalogues in $A S R$, updated with new discoveries as far as possible, and reflect my own opinion in those cases where the presence of portrait features is debated. The table is intended to give a general impression and does not claim to be exhaustive. I do not include sarcophagi where women are assimilated with the Muses or Aphrodite outside a specific mythological narrative context. There are a few one-off sarcophagi, such as those showing Protesilaos (discussed below) and Hylas (Zanker and Ewald 2004, 96-8: see also Birk, this volume) not included in these figures. I include here sarcophagi from Italian workshops which copy Roman metropolitan forms, but not sarcophagi from elsewhere in the Roman world. The addition of portrait heads to mythological figures is not generally found on the Attic or Asia Minor sarcophagi.

12 For surveys of mythological themes on Roman sarcophagi see Sichtermann-Koch 1975; Koch-Sichtermann 1982, 127-95; Zanker and Ewald 2004, 278-381. 
Table 1: Portraits on Mythological Sarcophagi

\begin{tabular}{|c|c|c|c|}
\hline Subject & $\begin{array}{l}\text { No. of sarcophagus } \\
\text { fronts where heads are } \\
\text { visible (total) }\end{array}$ & $\begin{array}{l}\text { No. with portrait } \\
\text { heads/unfinished } \\
\text { heads }\end{array}$ & $\begin{array}{l}\% \text {, where known, where } \\
\text { heads have portraits or are } \\
\text { unfinished }\end{array}$ \\
\hline $\begin{array}{l}\text { Achilles \& } \\
\text { Penthesilea }\end{array}$ & $13(24)$ & 9 & $69 \%$ \\
\hline Adonis & $12(24)$ & 1 & $8 \%$ \\
\hline Alcestis & $6(12)$ & 2 & $33 \%$ \\
\hline $\begin{array}{l}\text { Discovery } \\
\text { of Ariadne }\end{array}$ & $31(34)$ & 14 & $45 \%$ \\
\hline Endymion & 55 (107) & 17 & $31 \%$ \\
\hline $\begin{array}{l}\text { Hercules } \\
\text { Labours }\end{array}$ & $12(30)$ & 3 & $25 \%$ \\
\hline Hippolytos & $18(35)$ & 3 & $17 \%$ \\
\hline $\begin{array}{l}\text { Mars \& } \\
\text { Rhea Silvia }\end{array}$ & $3(6)$ & 3 & $100 \%$ \\
\hline Meleager & $59(136)$ & 7 & $12 \%$ \\
\hline Pelops & $5(7)$ & 1 & $20 \%$ \\
\hline Persephone & $48(80)$ & 4 & $8 \%$ \\
\hline
\end{tabular}

of these themes can also feature portrait heads, as we see on around half the Ariadne figures, and a third of Selene and Endymion figures. Other figures who sometimes gain portrait features are Alcestis, Heracles and Hippolytus.

The vast majority of these portraits (around $90 \%$ ) show hairstyles of the third century and it seems as though the period from 200-250 was the most popular time for portrait identifications. Indeed, in some groups of mythological sarcophagi almost all the third-century examples have portraits. ${ }^{13}$ During the second century (at least until the Severan period) portraits are much less common. This is also true of sarcophagi with the Muses or Erotes, which present a generic mythological world rather than a specific mythological narrative. Apart from a couple of early exceptions, these do not receive portrait features until well into the third century. ${ }^{14}$ On non-mythological sarcophagi the

13 Engemann 1973, 28, n. 124.

14 Exceptions: $A S R V, 2,1$, no. 5 (a sarcophagus in Berlin showing a young girl among Erotes); Moretti 1975, no. 8 (G. P. Begni) = Wrede 1981, no. 239 (Sarcophagus from Cività Castellana showing the portrait of a boy on the figure of a Muse, not in $A S R \mathrm{~V}, 3)$. 
taste for portraits seems to correspond to this general picture. Early examples of battle sarcophagi feature a series of separate combats without any individualisation of particular figures, only focusing on a central group around the turn of the third century when portrait features (or an unfinished head) begin to be added to the central figure. ${ }^{15}$ Lion hunt sarcophagi almost always give portrait (or unfinished) features to the central figure, but only begin to emerge around 230, developing out of the mythological hunt sarcophagi. ${ }^{16}$ Portraits appear rather earlier on the small group of 'Vita romana' sarcophagi showing the deceased as general, magistrate and husband which emerge around $170 .{ }^{17}$ Tondo portraits also begin to appear on Dionysiac and marine sarcophagi towards the end of the second century, filling with portrait faces shields or shells which had previously remained empty or bore simply an inscription. ${ }^{18}$

There seems to have been an increasing desire to include portraits on sarcophagi from the late second century onwards, though this ranged from images of the deceased on lids or shields, sometimes carried by mythological figures, to full identification of the deceased with a particular mythological character. Rather than seeing the addition of portraits to mythological sarcophagi as influenced by the display of narratives featuring the deceased on non-mythological sarcophagi the trend towards portraiture seems to occur on both mythological and non-mythological frieze sarcophagi roughly concurrently; in both it is erratic until the later second century and reaches its height in the third century, continuing even later on some sarcophagi types.

On some late sarcophagi, individual mythological figures could also be excerpted from their narrative contexts and represented with portrait heads. This can be seen on the Ariadne sarcophagi in Naples (from Auletta) and Copenhagen, as well as on the Endymion sarcophagus in the Palazzo Braschi and one in the British Museum where the central figure has been reworked from a female Ariadne figure to one showing Endymion. ${ }^{19}$ When such figures are taken out of their narrative context the question arises as to whether we should still think of them as showing the deceased in the guise of Ariadne or Endymion, or rather simply as a representation of the deceased in eternal

Both are dated mid second century. For discussion of portraits on these groups see ASR V,2,1: 109-113 (Kranz) and ASR V, 3: 128-33 (Wegner).

15 Andreae 1956; Schäfer 1979, 357-8.

16 See Andreae ASR I, 2 for analysis of the group. One late exception to this is a sarcophagus in the Palazzo dei Conservatori, dated to c. 280, which seems instead to allude to the hunting spectacles of the arena; $A S R \mathrm{I}, 2$, no. 110.

17 Collected in $A S R$ I,3 (Reinsberg). For a discussion of the meaning of the group see also Muth 2004.

18 Vita Romana: Tondo portraits: Matz 1971, see further ASR IV,4, 452-66 (Matz); ASR $\mathrm{V}, 1$ (Rumpf).

19 ASR IV,3, no. 229; Wrede 1981, cat.54 ; ASR XII,2, no. 102; Sichtermann 1966. See also Birk in this volume and Figure 7.5. 
repose ${ }^{20}$ It raises the question of what importance should be given to the events of the myth itself, as opposed to the qualities and attributes embodied in the figure of the hero or heroine. These isolated figures share some characteristics with the representations of humans in the forms of gods in statues or reliefs. Wrede's discussion of these figures, which appear from the later first century, suggests that they were used to embody particular qualities such as beauty, chastity, or success in business; their significance linked to this one point of correspondence. ${ }^{21}$ Similar figures also appear on sarcophagi where the deceased is shown in the guise of Venus or as one of the Muses, outside a narrative context. ${ }^{22}$ Here we might see the identification as stressing the beauty or education of the figure. When identifications are made in the context of particular mythological narratives, however, the events of the myth open up a wider range of options about which qualities and values are being expressed.

\section{Second-century Mythological Sarcophagi with Portraits: Loss, Virtue and Family Values}

While the majority of mythological portrait sarcophagi date to the first half of the third century, the earliest examples go back to the mid second century. ${ }^{23}$ The most famous example is the well-known Alcestis sarcophagus in the Vatican whose inscription provides us with important contextual information (Figure 6.1). ${ }^{24}$ This informs us that Gaius Junius Euhodus, of the Palatina tribe, made the sarcophagus for himself and his wife, Metilia Acte. She was priestess of the Magna Mater in Ostia, while he served as five-yearly magistrate of the guild of carpenters in the $21^{\text {st }}$ lustrum, $158-163 .^{25}$ The sarcophagus shows multiple heads with portrait features. The figure of Alcestis on her death-bed is given the features of an aging woman, with a hairstyle reminiscent of the early Antonine period, c. 140-150. Presumably this is the face of Metilia Acte herself. Behind this figure appear the heads of an old woman, also with an early Antonine

20 See the debate between Sichtermann 1966 esp. 82-7; ibid., ASR XII,2, 46-8 and Engemann 1973, 28-30; the literature is reviewed by Koortbojian 1995, 138-41.

21 Wrede 1981, 67-124.

22 Venus: e.g. clipeus portrait with deceased as crouching Venus, ASR V.1, no. 92; Zanker and Ewald 2004, 126-7, fig. 110. On Muses see Marrou 1938; Wrede 1981, 148-9.

23 On the fragment in Ostia showing Demeter with portrait head, dated to 140s, see below, n. 49. A Muse sarcophagus with the portrait of a boy from Cività Castellana is also early, c. 150; Moretti 1975, 259 f, no. 8 (G. P. Begni); Wrede 1981, 140-1, 285-6, no. 239.

24 ASR XII,1, no. 76. See also Wood 1978/1993; Zanker and Ewald 2004, 202-3, figs. $182-3 ; 298-30$, no. 8 .

25 CIL XIV.371. Dating of the lustrum: Fittschen 1984, 142, 160, n. 46; ASR XII,1, 111 (Grassinger). 


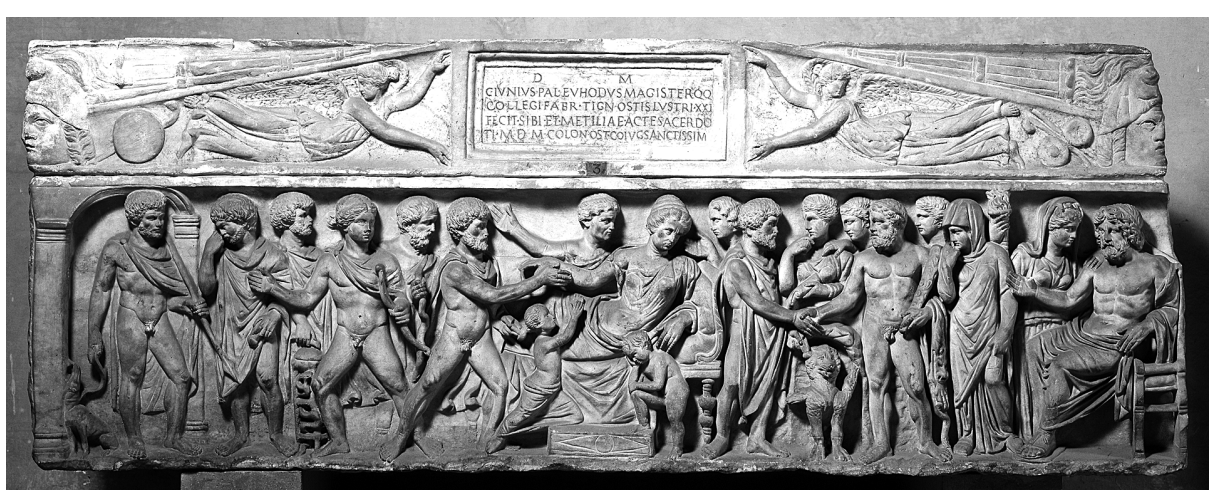

Figure 6.1: Alcestis sarcophagus, Vatican Museo Chiaramonti inv. 1195. Photo: Vatican Museums.

hairstyle, and of a younger woman with hair in the style of Faustina the younger, from c. 152. They may represent the features of members of Metilia and Euhodus' family. The figure of Admetus himself appears twice, approaching his wife's deathbed and clasping hands with Heracles. Both figures show portrait features with a hairstyle like that of the emperor Lucius Verus common from $160 .{ }^{26}$ The figures of an old man in the deathbed scene, and some of the hunters to the left also appear to have portrait features, again evoking members of the couple's wider family.

As Klaus Fittschen has noted, the hairstyles shown here actually span a period of some twenty years, though there is no indication that the portraits were executed at different dates and all seem to be contemporary with the working of the sarcophagus. ${ }^{27}$ Its date can be fixed to soon after 160 from the evidence of the inscription and Euhodus' portrait face. The fact that Metilia sports an earlier portrait type may be due to one of two factors: either she continued to wear a style which had already gone out of fashion, or she had, in fact, died some years earlier. If the latter, it is possible that she was initially buried in a simpler grave and it was only once Euhodus had gained increased wealth and prestige, notably in the form of his magistracy, that he decided to commission a new sarcophagus to commemorate them both. The presence of other family portraits on the sarcophagus need not necessarily mean that they had all died too, since they are not mentioned in the inscription, but it does draw attention to the wider family setting of the couple and suggests their grief

26 The hunter at the far left has also been seen as Euhodus because of his portrait features, but these differ markedly from the other two depictions: Blome 1978, 442-4; Zanker and Ewald 2004, 298; ASR XII,1, 125 (Grassinger). On the portraits see also Fittschen 1984, $141-3$.

27 Fittchen 1984, 141-3. 
at Metilia's death. Euhodus' membership of the Palatina tribe suggests that he was probably a freedman, a fact which may have motivated this display of extended family, an attribute denied to him while he was a slave. ${ }^{28}$

The sarcophagus is part of a smallish group of Alcestis sarcophagi which cluster in the second half of the second century. ${ }^{29}$ The majority of these do not have portrait features but show the same general scene of the death of Alcestis in the centre while Admetus is shown with a group of his hunters to the left. ${ }^{30}$ One in St Aignan, France, has a Greek inscription on the lid informing us that it was dedicated by a mother to her daughter; on others, such as the one in the Villa Albani, the stress is on grief at Alcestis' death, with figures showing gestures of distress. ${ }^{31}$ Grave poetry shows that the figure of Alcestis could be used as the prime exemplum of a virtuous woman: a bilingual Greek and Latin inscription from Sardinia marks the grave of a woman named Pomptilla who is said to have prayed to die in place of her husband when he was suffering from an illness. Her subsequent death is taken as proof of her outstanding loyalty as a wife. In the Greek section of the inscription Pomptilla is explicitly compared with various Greek heroines who were renowned for their loyalty to their husbands Penelope, Laodicea, Evadne and Alcestis. ${ }^{32}$ The addition of portrait features on the Vatican sarcophagus particularises the myth and also allows a greater stress on Admetus/Euhodus who is shown as loving husband as well as, in his heroic nudity, as a vibrant and vigorous figure. His handshake with Hercules, at the right end of the sarcophagus, also acts as a symbol of concordia, a virtue which was also prized on sarcophagi with scenes of Roman life. ${ }^{33}$

In its presentation of a dying woman lying on a couch with her family gathered around, the iconography of the sarcophagus also echoes imagery found on non-mythological sarcophagi of the period. The 'vita privata' sarcophagi and reliefs catalogued by Rita Amedick include examples of the deceased reclining on a kline which can feature quite detailed portraits, as on a loculus cover from Ostia where the woman's hairstyle suggests a date of c. $150 .{ }^{34}$ Closer to the picture of grief shown on the Alcestis sarcophagi are the images of relatives grieving for the death of a child which appear on biographical sarcophagi of children. ${ }^{35}$ These date from the Hadrianic period onwards and sometimes give reasonably precise features to the deceased or his/her parents, though elsewhere

28 On the Palatina tribe see Meiggs 1973, 190-1. It is also possible that some of the figures could have been fellow-liberti rather than family members.

29 Blome 1978, 435-45; ASR XII,1, 110-28 (Grassinger).

30 The chest in Genoa, ASR XII,1, no. 86, c. $200-210$, also has a worn portrait head.

31 ASR XII,1, nos. 75, 77.

32 IG XIV.607; CIL X.7563/78; Peek 1955, 636-40, no. 2005, 1. $22-31$.

33 ASR XII,1, 127 (Grassinger).

34 ASR I,4, no. *176.

35 ASR I,4: $72-4$ (Amedick). 
the faces are more generic. ${ }^{36}$ The sharing of visual types between mythological and non-mythological sarcophagi suggests the projection of Roman funerary values into a mythological world, perhaps as an extended poetic analogy expressing the virtues of the deceased. When portrait features are added these two worlds fuse together in a particular and powerful way.

In the grave inscription of Pomptilla she is compared not only to Alcestis, but also to Penelope, Evadne and Laodameia. Only the latter of these three appears on sarcophagi, in a one-off piece in the Vatican museum, dated to c. 170 (Figure 6.2). ${ }^{37}$ It shows the story of Protesilaus in a series of scenes, starting from the left short side where the hero's departure for the Trojan War is shown. On the front he is shown disembarking from the boat at Troy whereupon he is immediately killed. While his corpse lies on the ground his ghost (the heavily draped figure) is led down to Hades by Hermes. In the adjoining scene, however, we see the hero again, restored to his youthful form, being led by Hermes back to his palace for a reunion with his wife. ${ }^{38}$ This takes place in the centre of sarcophagus and is shown as a formal dextrarum iunctio in front of the doors of the palace. The figures of Protesilaus and Laodameia are assimilated to the poses of married couples on vita humana sarcophagi and both heads are unfinished. ${ }^{39}$ To the right of this scene the rest of the myth is retold, with their figures reverting to idealised forms. Laodameia lies grieving on her bed; the similarity to deathbed scenes such as those of Alcestis, discussed above, foreshadows her imminent suicide. To the far right Protesilaus is led back down to Hades, which is defined on the right short side by the scenes of the torments of the sinners Tantalus, Ixion and Sisyphus.

Only one other version of this myth survives on sarcophagi, a piece in Naples Santa Chiara which has a different iconography, showing Protesilaus' return to Laodameia as she reclines on the ground. ${ }^{40}$ The Vatican sarcophagus is thus a unique piece, probably designed as a special commission. This makes the unfinished state of the central portraits particularly interesting. The explanation sometimes offered for unfinished heads, that they were stock workshop pieces which never received the intended personalisation, clearly does not work for

36 The well-known biographical sarcophagus of a child in the Louvre gives quite precise features to the boy's mother, ASR I,4, no. 114, dated c. 150 (this does not include the death scene). For examples of possible portraits of the deceased see ASR I,4, nos. 60, 198 (later addition?) contra e.g. no. 2. The frequency and use of portraits on nonmythological sarcophagi would repay further study.

37 ASR III,3, no. 423; Zanker and Ewald 2004, 374-7, no. 35.

38 The story of Protesilaus is told by Apollodorus 3.30 and Lucian, Dialogues of the Dead 28 [23], 427.

39 On marriage sarcophagi see $A S R$ I, 3 (Reinsberg).

40 ASR III,3, no. 422, Zanker and Ewald 2004, 101-2, fig. 85. The myth also appears on the Velletri sarcophagus, along with a number of other myths: Andreae 1963, 34-5. 


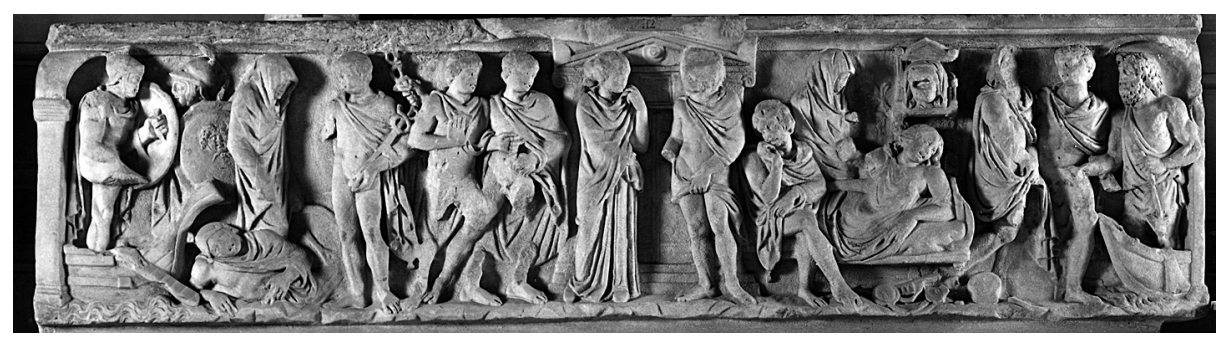

Figure 6.2: Protesilaus and Laodameia sarcophagus, Vatican Galleria dei Candelabri inv. 2465. Photograph: Vatican Museums.

what must have been an individual commission. ${ }^{41}$ On close examination it is also evident that the two faces do not show the same extent of a lack of finish. While the head of Protesilaus is left as a large undistinguished block of circular stone, that of Laodameia has been more finely worked with the result that we can see the impression of her features and the clear outline of her chin and hair. She appears to wear her hair in a large, low, bun on the back of the neck, in a style similar to that favoured by Faustina the Younger in the $160 \mathrm{~s} .{ }^{42}$ Other unfinished heads on sarcophagi show a similar range in the state of the heads, from blocks of roughly hewn marble, as for example on an Ariadne sarcophagus in Moscow, to blurred but recognisable outlines of faces such as that on the Ariadne sarcophagus of Maconiana Severiana, now in the J. Paul Getty Museum (see below, Figure 6.4). ${ }^{43}$

The usual interpretation of the Protesilaus sarcophagus is that it was made by a grieving wife for her predeceased husband, as would befit the course of the myth. ${ }^{44}$ Yet if this sarcophagus did commemorate a dead husband, why was the portrait of the dead man left so obviously unfinished? The fact that on this sarcophagus one head is more finished than the other leads me to interpret it not as a tomb for a dead husband, but one for a dead wife. This would explain why the head of Laodameia is more highly finished than that of Protesilaus, where the head is left as a mere block, possibly for portrait features to be added at a later date. Andreae has suggested that some heads were deliberately left unfinished as a form of aspirational statement about the dead, often on sarcophagi for children. ${ }^{45}$ The sketchy nature of Laodameia's face here might express the wish to imagine a reunion beyond the grave, rather than the certainly of such a union. Without the evidence of an inscription to help with

41 See Koch and Sichtermann 1982, 610-14; Andreae 1984 and Huskinson 1998 for fuller discussions of unfinished heads.

42 Fittschen 1982, 55-63 (types 7 and 8).

43 Moscow: $A S R$ IV,1, no. 47. Getty: previously Hever Castle, $A S R$ IV,3, no. 214.

44 Zanker and Ewald 2004, 99-100, 377.

45 Andreae 1984, 114-18, 125. 
interpretation we cannot know for certain who the sarcophagus was designed to hold and who commissioned it. However, the differing states of the portraits do, to me, suggest a monument to a dead woman rather than a man, even if it was eventually designed to hold them both.

This is certainly in conflict with the order of events in the myth where Protesilaus died first. However, in grave poetry references to Laodameia often appear in contexts where the death of a loyal and loving wife is lamented by her still-living husband. ${ }^{46}$ We can read the sarcophagus as an extended consolation to the bereaved along the lines of the following: 'Even in myth great lovers were separated by death, think of Protesilaus and Laodameia. Just as loyal and faithful a wife was X; so great a love has been sundered'. The placement of Laodameia and Protesilaus in the pose of a Roman married couple evokes the formal public union of this couple during life, while also extending the hope or desire for a reunion in the afterlife.

There are a couple of other examples of portraits on funerary art from this period. One is a relief in Venice archaeological museum which probably served as a slab covering a burial. Fittschen has convincingly interpreted it as showing the myth of Cleobis and Biton (as famously told in Herodotus, Histories 1.33). The figures of Cleobis and Biton are given portrait features, while their mother shows the hairstyle of the younger Faustina, suggesting a date in the $160 \mathrm{~s} .{ }^{47} \mathrm{It}$ would appear to commemorate the tomb of two sons, set up by their mother. Again, we can see this as a form of visual consolation. Grave poetry and inscriptions often feature the theme that those the gods love die young as well as the idea that those who meet an untimely death will be whisked away to dwell with the gods in the heavens. ${ }^{48}$ The imagery of this relief asserts a similar message in visual form, offering the hope that the boys will be received into a happy afterlife, while stressing both their pietas towards their mother and the gods and the love shared between the family, who are shown embracing at the far right of the scene.

These early examples of portrait sarcophagi from the 160s show the flexibility of mythological narratives and the desire of relatives to use myth to express messages about themselves and their loved-ones. ${ }^{49}$ As well as expressing

46 E.g. Peek 1955, 189, no. 727; 636-40, no. 2005; 688-9, no. 1737a.

47 Fittschen 1970; Sperti 1988, 142-51, no. 43. See also Zanker and Ewald 2004, $216-$ 17, fig. 195.

48 Lattimore 1942, 39-42, 259.

49 A fragment in Ostia showing a female figure in a chariot with portrait features is often identified as the portrait of a bereaved mother assimilated to Demeter searching for Persephone (Zanker and Ewald 2004, 94, 270, n. 45 with further bibliography; see also Blome 1978, 453-5 recognising the problems of iconography discussed here). While the figure resembles the Demeter on Persephone sarcophagi (e.g. ASR III,3, no. 372) she is here accompanied by a second female figure holding a flaming torch, elsewhere an 
the desire for consolation and the qualities sought in a wife or child (love, pietas, loyalty) they also show the cultural frame of reference of the deceased and their families, the widespread tendency to turn towards mythological analogies to express the truths of human life. In the process, they also proudly assert the educational level of these families, which seem to encompass both freedmen and higher status families. ${ }^{50}$

The sarcophagus of Metilia Acte is part of a series of Alcestis sarcophagi. On the chest in St. Aignan the addition of an inscription identifying the deceased as a daughter suggests that the myth may have been read as a symbol of the grief caused by a sudden loss. ${ }^{51}$ The addition of portraits to the Vatican chest draws out different aspects of the myth. It allows the sarcophagus to become not just a celebration of the wifely perfection of Metilia herself, but also a proud statement of the status of Junius Euhodus whose magistracy is mentioned in the inscription, and who is shown in the mythological scenes as a loving husband, vigorous figure, and welcoming host. His place within a wide family, something which he as a freedman would have particularly valued, is also expressed by the numerous portraits of the figures around Metilia's deathbed.

These sarcophagi come from a period when the genre of sarcophagus art was still developing, and a number of chests were created as one-off commissions. ${ }^{52}$ At the same time, marriage and magistrate sarcophagi with portraits began to appear. $^{53}$ It was a period of experimentation, showing the desire to use this new form of funerary decoration to express the qualities valued in human life via the time-honoured analogies of myth. Portrait heads are relatively rare here, but when added they act in a similar way to inscriptions. They can extend the message of the myth and stress particular aspects, such as Admetus' manly virtue, or Laodameia's loyalty, as well as familial grief. Portraits and inscriptions do not just add specificity, they also direct us to the elements of the myth which are seen as particularly important for the commemoration of a particular individual, perhaps suggesting a desire to control the messages offered by this new form of funerary imagery. After this initial period of experimentation, however, the addition of portrait heads to mythological scenes largely disappears again until the Severan period.

attribute of Persephone. If Persephone too is shown here this is unlikely to be a fragment from a Rape of Persephone sarcophagus and may instead assimilate the deceased to Demeter to convey ideas of her fecundity, as in some funerary statues, Wrede 1981, 213-19.

50 The question of social status is too complex to discuss here. Freedmen are particularly well-represented in all areas of funerary art (see Mouritsen 2005 with further references) but there is also evidence of senatorial families commissioning mythological sarcophagi, e.g. $A S R$ IV,1, no. 26; ASR IV,3, no. 214.

51 ASR XII,1, no. 75.

52 E.g. the so-called Peleus and Thetis sarcophagus, Müller 1994.

53 ASR I,4 (Amedick). 


\section{Portraits on Later Mythological Sarcophagi}

The majority of portraits on later mythological sarcophagi are found on sarcophagi with three themes: the discovery of Ariadne, Selene's visit to the sleeping Endymion, and Mars approaching the sleeping Rhea Silvia. These share a number of compositional similarities as can be seen from the combination of the myths of Selene/Endymion and Mars/Rhea Silvia on a sarcophagus in the Vatican (below, Figure 6.6) and in the reworking of an Ariadne-type figure to serve as a male Endymion on a sarcophagus in the British Museum. ${ }^{54}$ However, a careful analysis of the use of portrait features suggests that the messages these scenes conveyed could vary substantially.

\section{Ariadne}

Sarcophagi showing the discovery of Ariadne by Dionysus form a sub-set of the much larger group of Dionysiac sarcophagi which generally show the god and his followers in scenes of revelry and triumph..$^{55}$ The prominence of the group varies greatly. While it is sometimes placed in the centre, it is often only one element in a much larger scene of Dionysiac worship and revelry. ${ }^{56}$ On some pieces the addition of portrait features help to draw attention to the scene. A sarcophagus once on the Paris art market shows the discovery scene prominently placed in the centre but surrounded by figures of dancing maenads and, at the far right, a scene of sacrifice. ${ }^{57}$ Here the figure of Ariadne seems to have portrait features. Her hair is parted in the middle and falls over her ears, with shoulder locks, in a manner similar to portraits of the younger Faustina and Lucilla, and her eyes are open. ${ }^{58}$

On the majority of the sarcophagi with portraits, however, Ariadne is not given a prominent position in the centre of the sarcophagus. Indeed, on a group of vat-shaped sarcophagi showing the Triumph of Dionysus, she is often relegated to a side position underneath a lion's head. ${ }^{59}$ An example in Blenheim shows the drunken Dionysus standing in the centre of the sarcophagus,

54 ASR III,1, no. 92; ASR XII,2, 54 f. (Sichtermann); Koortbojian 1995, 135-8.

55 ASR IV,3, 360-404, ASR IV,1 (Matz).

56 For an example where it is more prominent, without portrait features, see $A S R$ IV,3, no. 225; Engemann 1973, 28, n. 123.

57 ASR IV,3, no. 317.

58 Scholars have been reticent about calling this a portrait, though Matz (ASR IV,3, 389) noted the late Antonine hairstyle. Engemann 1973, 28, n. 122 denies a portrait on the grounds of the shoulder locks, but these are found elsewhere.

59 On the group see $A S R$ IV,1, 146-56. 
surrounded by his entourage. ${ }^{60}$ The sleeping Ariadne (without a portrait head) lies to the right, beneath a lion's head, and is mirrored on the left side by the reclining figure of Heracles. Rather than seeing this primarily as a representation of the union of Dionysus and Ariadne, we should probably see her here instead as simply one more attribute of the god himself. Yet on some sarcophagi of a similar type Ariadne is indeed given portrait features. An example in Bolsena, dated to the early Severan period, shows on the front Dionysus standing between Hercules and a satyr. ${ }^{61}$ A maenad rushes off to the right. Even further to the right the sleeping Ariadne appears beneath the lion's head boss, her body following the curve of the sarcophagus around the right end. Compositionally she is the pendant to a reclining figure of Tellus or Gaia on the left, who holds a cornucopia. The visual stress of the image is upon Dionysus, and his proud and confident pose. Yet Ariadne here is given portrait features, only really visible when we look at the sarcophagus from the right end when we see that she wears a hairstyle of the late Antonine/early Severan period. The portrait head might have been included to make the identification between the deceased and Ariadne clearer, on a design which did not really concentrate on her. It is also possible that the setting of the sarcophagus in the tomb privileged this viewpoint, particularly if it was displayed on the right wall of a tomb and approached from the right side. The addition of portrait features here can be read as a conscious effort to make a connection between deceased and mythological figure, on a visual type which did not, in itself, readily accommodate this.

A couple of other examples appear on fragments in Oslo and Paris. On both the figure of Ariadne is again pushed to the right, curved, end of the sarcophagus. On the fragment in Oslo she has portrait features, while on the piece in the Louvre the face is unfinished. ${ }^{62}$ While Ariadne is here identified with the deceased, the composition of these sarcophagi as a whole did not stress the discovery of Ariadne by Dionysus and their ensuing union, but rather her place as part of the Dionysiac realm. Rather than supporting the interpretation of these sarcophagi as a sign of the apotheosis of the deceased through divine union with the god, here the dead woman is shown lying in a state of blissful sleep amidst a Dionysiac realm, perhaps offering a consolatory message to her bereaved relatives. ${ }^{63}$

60 ASR IV,1, no. 45.

61 ASR IV,1, no. 46.

62 Oslo: ASR IV,1, no. 46a; see also L'Orange 1962, 41-2. Louvre: ASR IV,1, no. 49.

63 On apotheosis see Engemann 1973, 28; Wrede 1981, 142-5. 


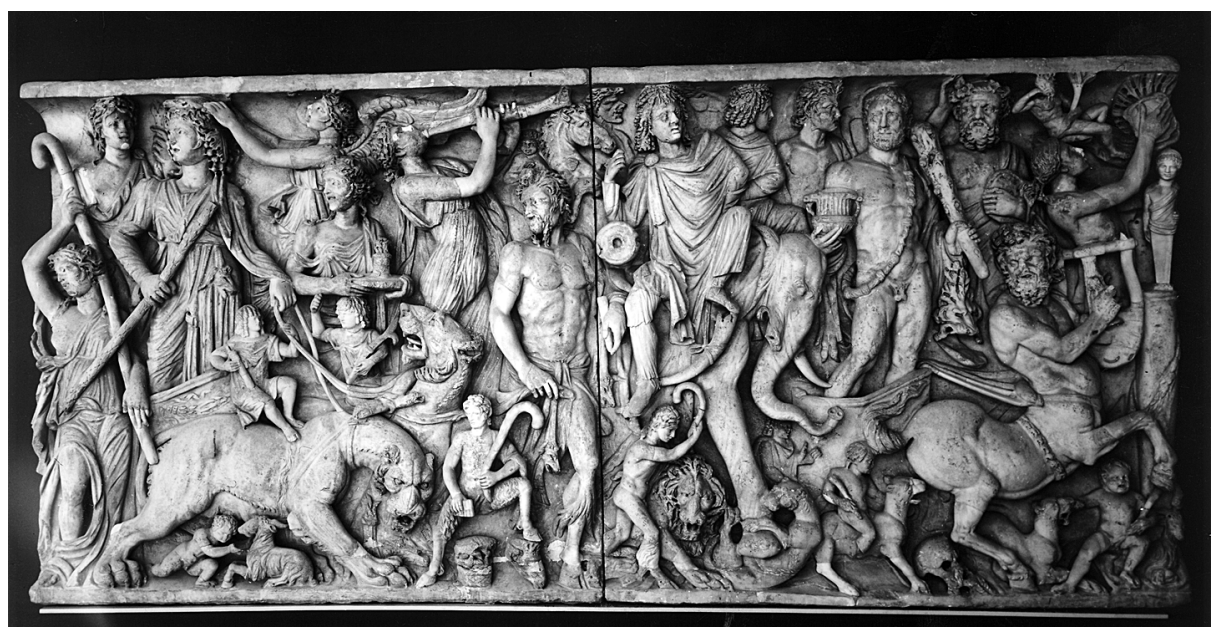

Figure 6.3: Dionysiac Triumph sarcophagus, Woburn Abbey.

Photograph: (C) Forschungsarchiv für römische Plastik Köln, neg. no. 1112.14.

Another sarcophagus which places the deceased in the Dionysiac realm via the use of portrait features is the unusual piece in Woburn Abbey (Figure 6.3). ${ }^{64}$ This shows a densely packed scene of Dionysiac triumph with the god himself appearing in a chariot drawn by tigers at the left edge. To the right of the relief appears another chariot, this time drawn by centaurs and holding the figure of Hercules who appears naked except for a wreath and his lionskin, and holding his club and a wine krater. Unlike the drunken figures of Hercules which appear on some other Dionysiac sarcophagi, he is shown as an imposing figure. He wears a portrait head with hair and beard of the early third century. The deceased is thus placed into a context of Dionysiac feasting and revelry but assimilated with the powerful god Hercules, rather than the more effete Dionysus. Dionysus seems to have been generally an inappropriate figure to identify an adult male with, although a couple of examples do exist. ${ }^{65}$ Here, the figure of Hercules offered a powerful, virile, model which also allowed for the male deceased to be shown as part of the Dionysiac realm.

Other Dionysiac sarcophagi stress the union of Ariadne and the god more clearly. On a vat-shaped sarcophagus in Moscow the figure of Ariadne is moved

64 ASR IV,2, no. 100, Matz dates it to Caracalla's reign; Angelicoussis 1992, 75-8, no. 78 (220-230); Zanker and Ewald 2004, 161, fig. 146 (c. 240).

65 The figure of the drunken Dionysus is given a portrait head on a strigillated sarcophagus in the Praetextatus catacombs: Wrede 1981, 155, 263, no. 181; Zanker and Ewald 2004, 160, fig. 145. A sarcophagus in the Museo Nazionale Romano which shows Dionysus and Ariadne enthroned may also have unfinished portrait features: Zanker and Ewald 2004, 164, fig. 150. 


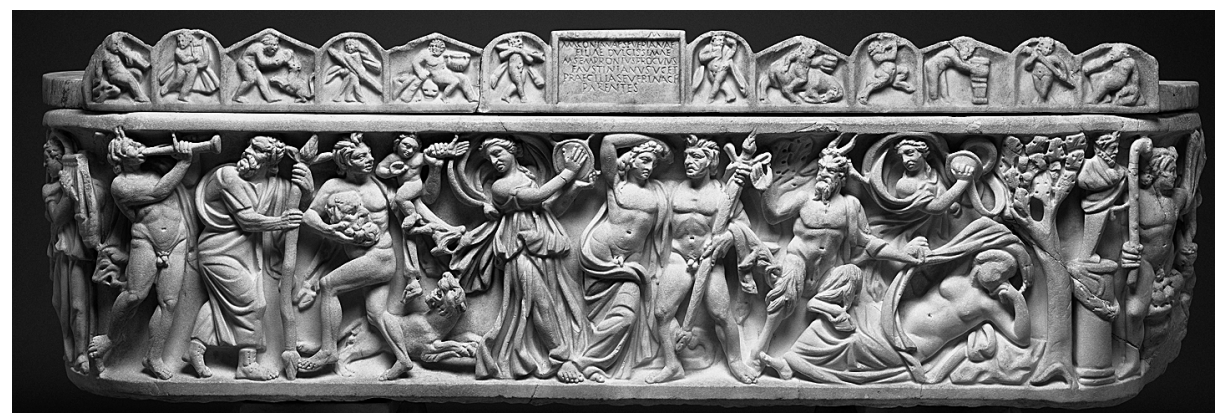

Figure 6.4: Sarcophagus of Maconiana Severiana showing the Discovery of Ariadne. The J. Paul Getty Museum, Villa Collection, Malibu, California. No. 83.AA.275 (Sarcophagus and Lid, Marble 210-220 AD, artist unknown). Photograph: museum.

closer to the god, to the left of the lion head boss. She has her head left as an unworked block to receive portrait features, though these were never completed. ${ }^{66}$ Other examples are rectangular in shape and seem to belong in the mid-to-late Severan period. A sarcophagus in the Palazzo Borghese in Rome shows Dionysus descending from his centaur chariot to approach the sleeping Ariadne, who lies with one breast bared, and has a portrait and Severan hairstyle. ${ }^{67}$ Another piece in the Hermitage Museum has a figure of Ariadne with a portrait and hairstyle of the late Severan period. ${ }^{68}$ Two other pieces show unfinished heads. On the sarcophagus of Maconiana Severiana, the daughter of a senatorial couple, the head of Ariadne is left sketched out without a complete portrait (Figure 6.4). ${ }^{69}$ Given the care and cost spent on the sarcophagus it seems likely that this was a deliberate decision on the part of her parents, possibly to express their hope that she was now in the Dionysiac realm, and perhaps that she might meet in the afterlife the husband who had been denied her in life. The unfinished portrait might allude to the girl's own untimely death, and the incompleteness of her life, whose natural progression to marriage and womanhood could now only be completed beyond the grave. ${ }^{70}$

A second sarcophagus on which the portrait was left unfinished is a chest in the Louvre, found with a companion piece showing Selene and Endymion in a tomb in Bordeaux. ${ }^{71}$ The sarcophagus seems to have been designed for a couple. The figure of Ariadne has her face unfinished, but with the outline of the hair

66 ASR IV,1, no. 47.

67 ASR IV,3, no. 223.

68 ASR IV,3, no. 212; Matz suggests that the sarcophagus was carved earlier and the portrait added to an unfinished head at the time of use.

69 ASR IV,3, no. 214; Andreae 1984, 114; Walker 1990 discusses the sarcophagus in depth, including the difficulties of dating.

70 Andreae 1984, 114; Huskinson 1998, 144.

71 ASR III,1, no. 72; Zanker and Ewald 2004, 108-9, figs. 91-2. 
drawn in. On the lid a male figure wearing a toga is also left with his face unfinished. The sarcophagus would thus seem to have been designed for a couple where the woman died first. By representing her as Ariadne her bereaved husband might have wanted to stress her beauty and desirability, through her nudity, and his hopes that she rest at peace in the afterlife. He himself is represented as a Roman citizen through the formal pose on the lid. The reasons for these portraits remaining unfinished are deeply obscure. The piece would have been an expensive commission and seems deliberately designed to belong with its companion Endymion piece where the portraits also remain unfinished. The space for the dedicatory inscription on the lid is also left blank. It may be that there was a deliberate decision made to leave the portraits unfinished, though it is harder to explain why a realistic portrait such as that on the lid would have been neglected. Perhaps this is a case of a sudden change of plan or circumstances; the man himself may have died before he was able to see through the completion of the sarcophagus and his heirs failed to carry it through. ${ }^{72}$

\section{Endymion}

The companion piece to the Louvre Ariadne sarcophagus shows the myth of Endymion. ${ }^{73}$ The central figures of Selene and Endymion are shown against a background which is packed with figures; shepherds, goats and personifications fill every inch of space. Selene and Endymion are marked out by their size, which is shared by only a few other figures, and especially by the unfinished heads which are roughed out enough to tell the general outlines of the hairstyles. The space on the lid for an inscription is left bare. While we assume that a specific couple is commemorated here, their identity and features remain obscure to us.

This sarcophagus is one of a number which show portrait features or the provision for them on both Endymion and Selene. ${ }^{74}$ The aim of these sarcophagi seems to be to draw a clear comparison between Selene and Endymion and the love between a married couple. The addition of portrait

72 Robert (ASR III, 1, 86) notes that the sarcophagi were found piled on top of one another, apparently in a fourth-century context, which might suggest reuse. While the imagery suggests that they were designed for couples, only one skeleton was found inside each - a female skeleton in the Ariadne sarcophagus and a male one inside the Endymion sarcophagus. Robert had suggested that they were made for the husband and wife of one couple but Wrede 1981, 265-66, no. 185 notes that the shape of the hairstyle on Selene is different from that on Ariadne. Perhaps they were initially designed for two couples of the same family.

73 ASR XII,2, no. 72.

74 ASR XII,2, nos. 56, 73, 76, 77 (see Vighi 1935, 246), 92, 93, 95. 
features to the mythological characters may be aimed at tying down the interpretation of the myth. Discussions of the funerary symbolism of this myth have ranged widely, from stressing the use of sleep as an analogy to death - the sleeping Endymion thus represents the dead person buried within - to seeing the myth as a complex metaphor for the apotheosis of the soul after death, as proposed by Franz Cumont. ${ }^{75}$

Koortbojian discerns a number of different messages in the myth suggesting that the central scene embodies the deceased's encounter with the divine while the bucolic scenes which surround the main image suggest a pastoral oasis of peaceful meditation. ${ }^{76}$ On this reading Endymion represents the deceased man, perhaps presented in a consolatory way where sleep is compared to death and the dead shown residing in an idyllic bucolic setting. However, Koortbojian also draws attention to suggestions that it is through sleep that people communicate with supernatural forces - both with the gods and with the dead. According to this interpretation Endymion would not be dead, but the bereaved party, and the visitation of Selene compared to the dead wife's appearance in her husband's dreams. ${ }^{77}$ On the sarcophagi where Selene and Endymion are given portrait features which are also idealised, for example through the addition of shoulder locks to Selene's image, the message could be seen as one of aspiration rather than faith, a statement by which the bereaved husband expresses his hope of seeing his dead wife in his dreams, or of a final reunification after death. ${ }^{78}$ Such hopes are expressed in some funerary inscriptions; in one from Rome a wife prays to see her dead husband in her dreams and hopes that she will soon join him in death. ${ }^{79}$

When portraits are added to both figures, the stress seems to be on the assimilation of the couple's love to that of Selene and Endymion, rather than to Endymion's apotheosis or happy afterlife. If Endymion alone is shown, however, the message might be a stronger assertion of a faith in a happy afterlife. There are a number of fragments where Endymion has a portrait head, or his features unfinished in preparation for one; in many cases, however, we are lacking the figure of Selene and thus cannot tell whether she too might have been designed to have a portrait. ${ }^{80}$ On one striking example, however, we find the figure of Endymion alone: a sarcophagus in the Palazzo Braschi in Rome where Endymion is shown with his eyes open and with portrait features, in the

75 Cumont 1942; Sichtermann (ASR XII,2, 41-53) discusses the symbolism of the myth.

76 Koortbojian 1995, 73-84, esp. 83.

77 Koortbojian 1995, 106-111.

78 Shoulder locks appear on ASR XII,2, nos. 93 and 95.

79 CIL VI,18817, discussed and translated by Koortbojian 1995, 108.

80 ASR XII,2, nos. 49, 85, 90. 
company of the figures of Eros, the drunken Dionysus and Mars and Venus. ${ }^{81}$ His pose clearly associates him with the figure of Endymion, but the mythological narrative is lacking - perhaps here we have a much stronger statement that the deceased was as beautiful as Endymion and is now at peace in the company of the gods. ${ }^{82}$ The beauty of these dead men is sometimes stressed by their nakedness, as is their erotic allure. Here, perhaps, we have a figure who died before he had a chance to marry, whose vitality and desirability are stressed and proclaimed to make him the equal even of those beloved by the gods. ${ }^{83}$

One thing that is striking on the Endymion sarcophagi is that while human males are assimilated to heroes, as we see elsewhere on sarcophagi, the women are identified with a goddess. This is rare on other types of sarcophagi, though it does appear on grave statues in the round.$^{84}$ On many sarcophagi it is Selene, rather than Endymion, who occupies the central position. On an impressive sarcophagus in Woburn Abbey the goddess is given the portrait features of a mature woman who wears her hair in the style of the 250s (Figure 6.5). ${ }^{85}$ Endymion's head, however, is left unfinished, though in the sketched-out technique which characterises other sarcophagi where there seems to have been a deliberate decision to leave the head unfinished.

The concentration on Selene here suggests that the sarcophagus was either commissioned by, or primarily designed for, a woman. However, it is unlikely that it was commissioned by a still-living husband for his dead wife. The impression of Endymion's portrait face is rather more youthful than that of the woman and shows no signs of the beard usually worn by mature men. If the sarcophagus was commissioned by the woman before her death, he may represent a husband who had died young, or possibly even her son. Mother-son relationships seem to be alluded to on other mythological sarcophagi, even when the myths concerned dealt with sexual relationships between men and women. The Theseus sarcophagus in Cliveden gives the abandoned Ariadne features which are much older than those on the figure of Theseus, suggesting that she may be identified with the mother of the deceased buried within, seventeen-year-old Artemidorus, whose features appear on the figures of Theseus. ${ }^{86}$ The sarcophagus of Hippolytus in the Museo Nazionale Romano turns the scene of Phaedra's illicit love for her stepson into a scene of grief by a mother for her dead son, whose education is stressed by the fact that the letter he

81 ASR XII,2, no. 102.

82 On this sarcophagus see Sichtermann 1966; Koortbojian 1995, 135-41.

83 Cf. the sarcophagus of Maconiana Severiana, discussed above.

84 Wrede 1981, 67-139.

85 ASR XII,2, no. 94; Wrede 1981, 267, no. 189 (250-260); Angelicoussis 1992, 85-8, no. $65(250)$.

86 ASR III,3, no. 430; Blome 1992, 1062-5. 


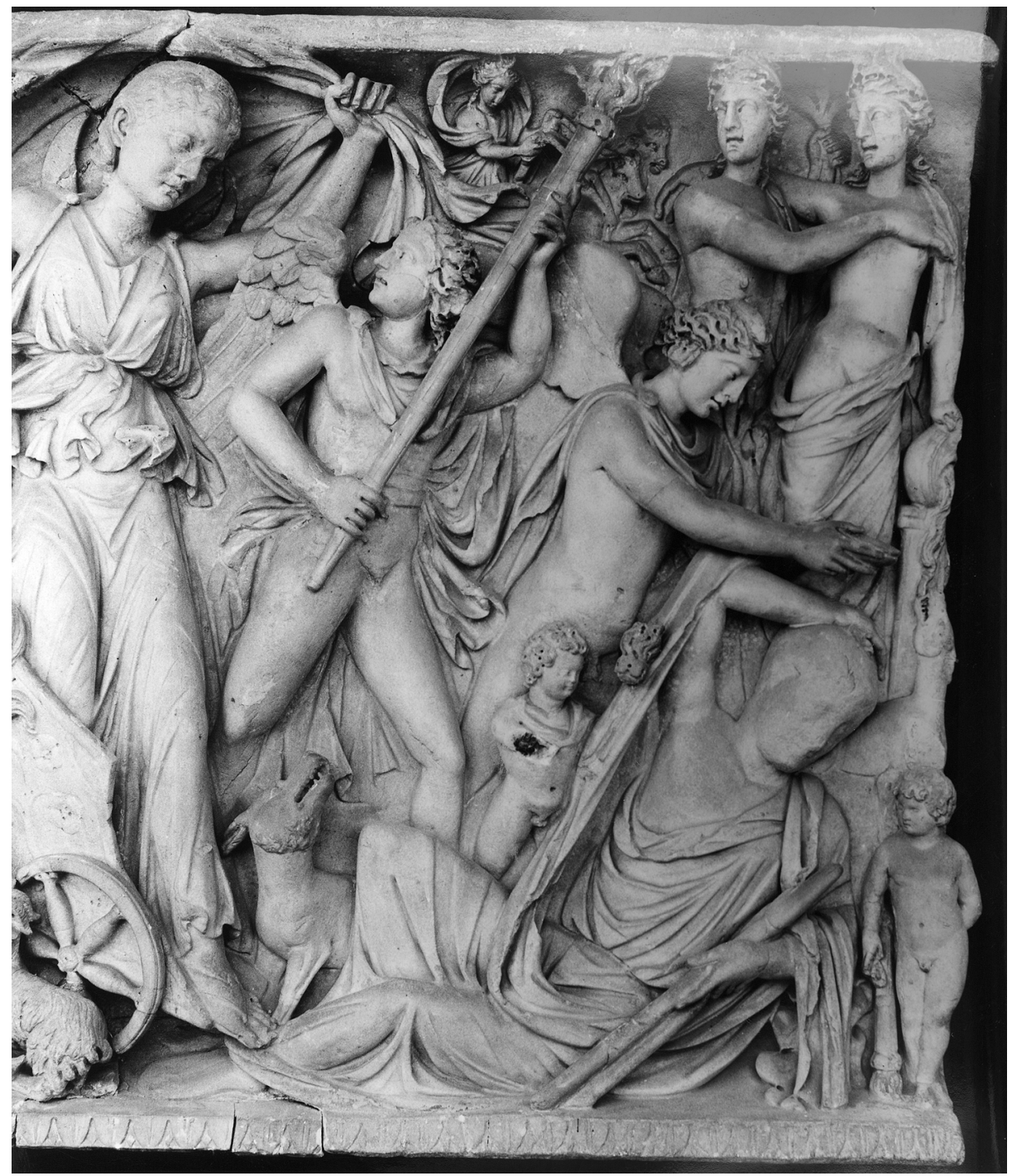

Figure 6.5: Selene and Endymion sarcophagus, Woburn Abbey; detail.

Photograph: (C) Forschungsarchiv für römische Plastik Köln, neg. no. 1134/2.

carries is portrayed as a diptych. ${ }^{87}$ On the Woburn Abbey sarcophagus we could be dealing with the expression of the hope that mother and son will be reunited in death. It is impossible to tell whether this was a commission before her death by a woman whose son (or husband) had already died, or by a still living son whose representation in the form of the sleeper Endymion alludes to his

87 Zanker 1999. 
sightings of his mother in his dreams. In either case, the mismatch in the portraits suggests a separation in the circumstances of the two figures, and the expression of a hope for reunification rather than the certainty of resurrection.

It is important to remember that when inscriptional evidence is provided it often reveals a use of sarcophagi imagery which is contrary to that we would expect. On an Endymion sarcophagus in New York the inscription and portrait on the lid reveal the sarcophagus to have been chosen not to commemorate the death of a young man, but rather as a dedication by a woman to her dead mother ${ }^{88}$ Like the personalising inscriptions, portrait heads too could help to give a new twist to a mythological analogy, selecting from a range of interpretative options the one which was particularly desired by the commissioner. The great popularity of the Endymion myth as a theme for sarcophagi might well have been precisely its flexibility and range of meanings: sleep as a metaphor for death, the hope of a happy slumber in an idyllic realm, the belief that the youthful beauty of the deceased ought to bring them divine salvation, or the hope for marital reunion beyond the grave. All of these interpretations, and more, were available for selection and stress by changing the details of dress and portrait features.

\section{Mars and Rhea Silvia}

Whereas Ariadne sarcophagi seem to celebrate the beauty and desirability of a deceased woman and to express the hope that she will find peace within the Dionysiac joys of the afterlife, the Selene and Endymion sarcophagi could commemorate either a deceased man alone, or both partners in a couple, celebrating their hopes for reunion and their enduring love. The celebration of marital love also provides the theme for the small group of Mars and Rhea Silvia sarcophagi, which are closely linked to the sarcophagi of Selene and Endymion. In this myth the roles are reversed with the male taking the active role. Where we can tell, all the monumental representations of the scene seem to have portrait features, all dating to the first half of the third century. ${ }^{89}$

A sarcophagus in the Vatican represents the myths of Rhea Silvia and Endymion side by side, with portrait heads on the figures of Mars and Rhea

88 ASR XII,2, no. 80. It has been suggested that this is an example of reuse of a earlier sarcophagus. See also the sarcophagus dedicated to Gerontia in the Capitoline Museum, $A S R$ XII.2, no. 27. In either case, the mythological imagery might still have had some resonance.

89 The two exceptions are sarcophagi where the couple appear as one motif among a number of scenes: ASR III,2, no. 192 (columnar sarcophagus), di Mino and Bertinetti 1990, 89-92, no. 67 (A. Bedini, clipeus sarcophagus). 


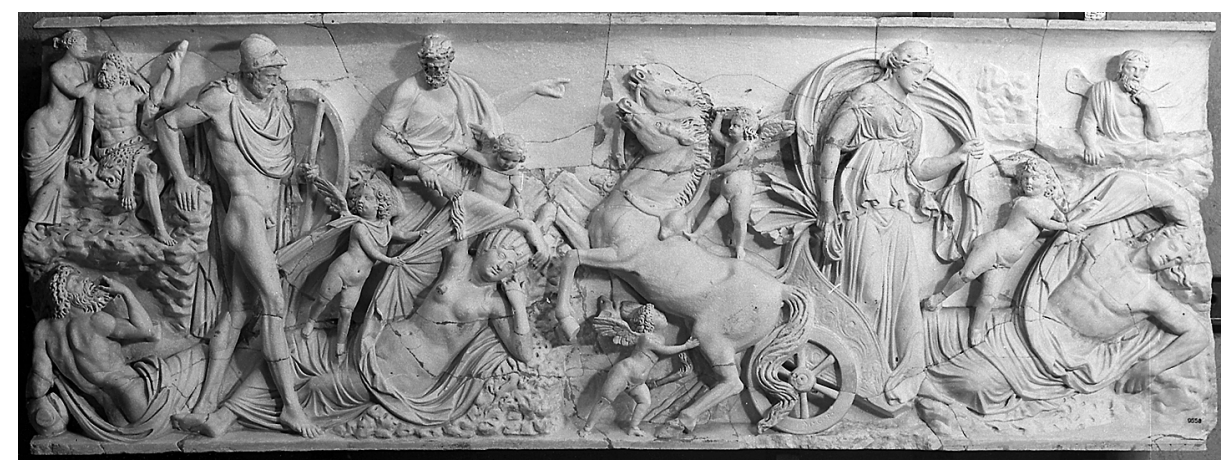

Figure 6.6: Mars and Rhea Silvia Sarcophagus, Vatican Museo Gregoriano Profano inv. 9558. Photograph: DAIR 74.535.

Silvia (Figure 6.6). ${ }^{90}$ Fittschen has noted that whereas Rhea Silvia wears a hairstyle of the early Severan period (Figure 6.7), the face of Mars is reminiscent of the period of Caracalla, some 10-15 years later (Figure 6.8). ${ }^{91}$ The female portrait is marked by its youthfulness, while that of Mars is older, with lines across the forehead. It seems likely that the sarcophagus was commissioned by a man while still alive to commemorate himself and a wife who had died some ten years before. Her portrait may have been completed following a death mask or portrait bust, and her remains transferred to the new coffin. The man's devotion to his wife even after years without her is expressed by his decision to commission a sarcophagus commemorating them both, and perhaps expresses his hope for a reunion in the afterlife. She seems to lie in a trancelike, timeless state, with eyes which are open but unseeing, her nakedness expressing her nubile beauty (Figure 6.7). The man's portrayal in the form of the active war god heroises him and draws attention to his own virtues and vigour as well as to his love for his wife. Whether the figures of Selene and Endymion also had portrait features on this sarcophagus is unknown because both heads are restored. However, it seems unlikely. The second couple may have been added to provide another mythological analogy for the love of the couple, and because of the typological similarities between the two situations. The general message of the imagery might be reconstructed as follows: 'I, as vigorous as Mars, hope to be reunited with my beautiful wife who lies sleeping in the afterlife, just as Mars was united with Rhea Silvia, and Selene with Endymion.'

The second example where the heads of both protagonists are preserved is a sarcophagus in Palazzo Mattei in Rome which sets the central figures against a

90 ASR XII,2, no. 99.

91 Fittschen 1984, 160, n. 47a. He suggests that the sarcophagus style also dates to the period of Caracalla. 


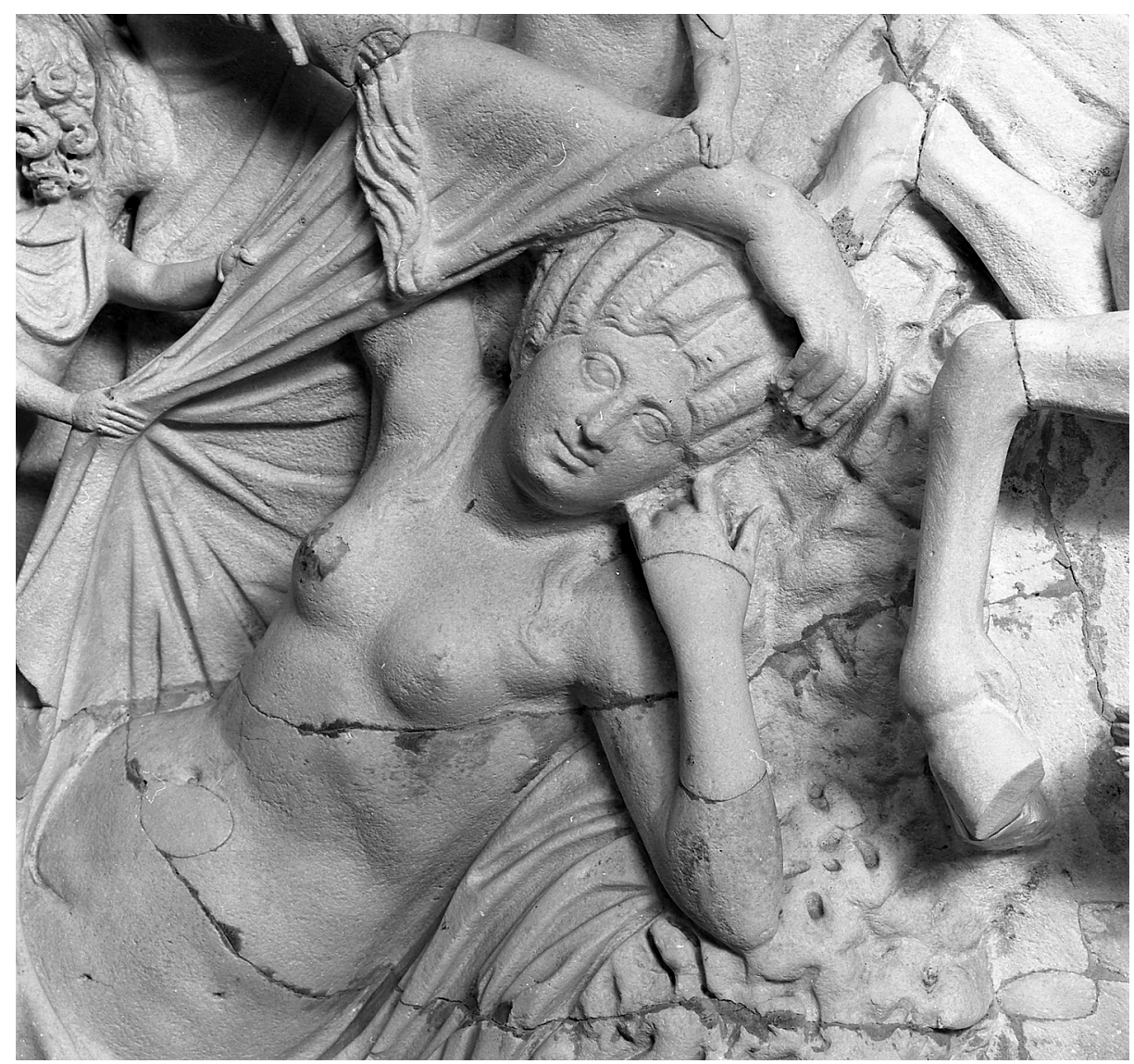

Figure 6.7: Mars and Rhea Silvia Sarcophagus, detail. Photograph: DAIR 74.539.

background of subsidiary personifications (Figure 6.9). ${ }^{92}$ Here too, Fittschen suggests that the portrait types represent different periods. He dates the hairstyle of the woman to the border between the early and mid Severan period, whereas he sees in the portrait of the man features of the period $240-250$. He concludes that the sarcophagus dates to the latter period. ${ }^{93}$ However, other evidence suggests that the sarcophagus dates to the late 220s. The hairstyle worn by Rhea Silvia is similar to those worn by Julia Mameaea and Orbiana (respectively the mother and wife of Alexander Severus) and the short beard and moustache worn by the figure of Mars have parallels in the portraiture of Alexander Severus

92 ASR III,2, no. 188; Guerrini 1982, no. 61. Another sarcophagus in the Palazzo Mattei (ASR III,2, no. 190; Guerrini 1982, no. 60) has the lower half, including the figure of Rhea Silvia, restored.

93 Fittschen 1984, 149. 


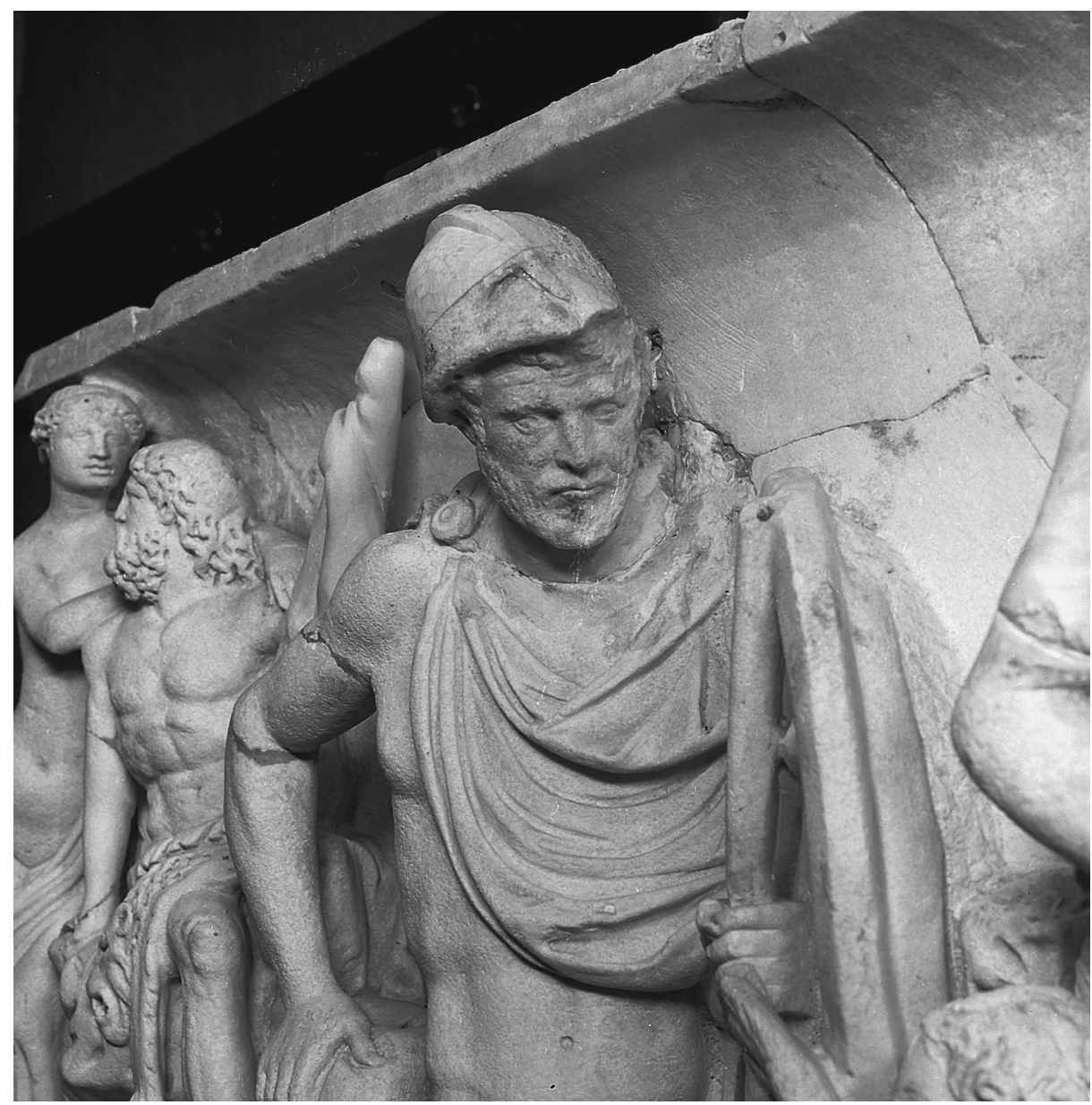

Figure 6.8: Mars and Rhea Silvia Sarcophagus, detail. Photograph: DAIR 74.540.

himself. ${ }^{94}$ There is no obvious difference in ages between the two figures and it seems safest to assume that they do represent a married couple, though perhaps here too the wife died first and the sarcophagus was commissioned by her husband to commemorate them both.

This sarcophagus front has been linked with two short sides in the Vatican, one of which shows the discovery of the twins Romulus and Remus being suckled by the she-wolf. Unlike the majority of mythological scenes found on

94 Guerrini 1982, 215. Orbiana was wife of Alexander Severus between 225-227. A coin portrait of Alexander wearing a short beard and moustache is dated to 228: Wiggers and Wegner 1971, 179, pl. 45e (Sesterce 515). The evidence thus supports a date in the late 220 s for the sarcophagus. 


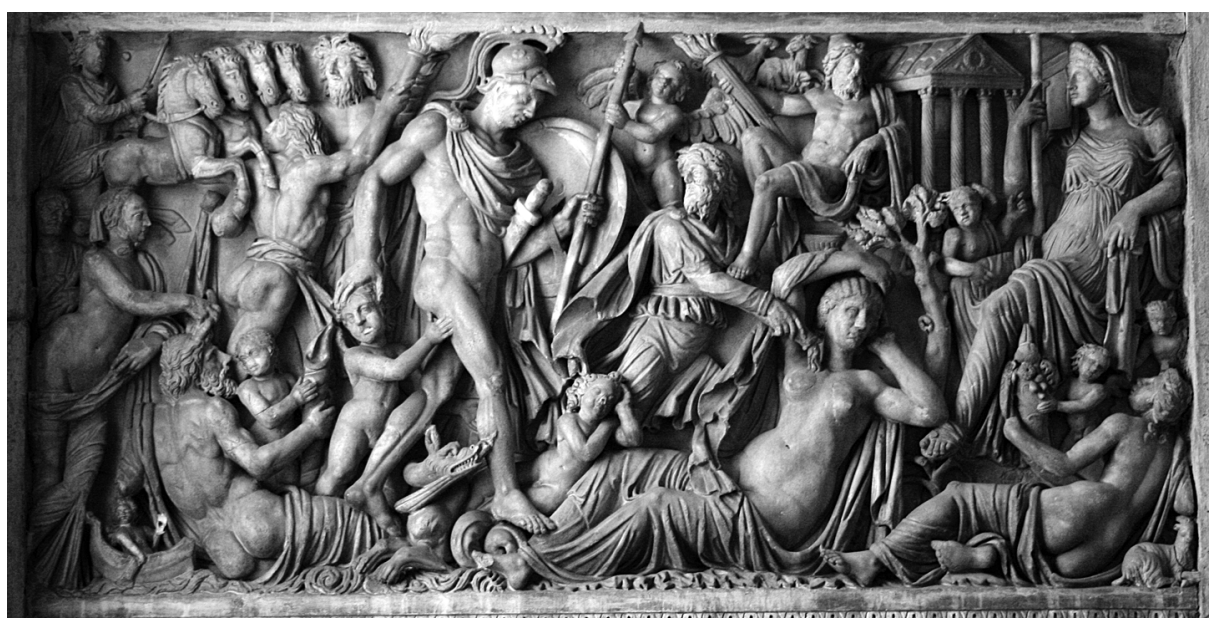

Figure 6.9: Mars and Rhea Silvia Sarcophagus, Palazzo Mattei, Rome. Photograph: author.

sarcophagi, this one relates specifically to the history of Rome. The derivation of the type perhaps emerges from a desire to identify both partners of a couple with a mythological couple, and to show the male taking the active role. Scenes of Dionysus and Ariadne were unsatisfactory to express this because Dionysus was an inappropriate god with whom to identify a male Roman citizen. Mars, however, could express the martial vigour of the dead husband, while Rhea Silvia could express the wife's desires and hopes to be reunited with her husband in the afterlife. The use of a myth central to Roman identity might also have given an added resonance to these sarcophagi, representing the deceased couple in the guise of the very founders of the Roman race. ${ }^{95}$

\section{Achilles and Penthesilea}

The mutual love between a couple is the central message of another group of sarcophagi where both male and female protagonists commonly receive portrait features. The group of Achilles and Penthesilea sarcophagi emerges around the start of the third century from a group of battle sarcophagi showing the Amazonomachy. ${ }^{96}$ Here, however, the stress is changed from the presentation in the central group of a Greek warrior holding the corpse of an Amazon, to the representation of Achilles supporting the slumped body of the Amazon queen. The size of the figures relative to the background figures is also increased to

95 Cf. statues of couples as Mars and Venus, Wrede 1981, 133-5. Another sarcophagus on a Roman mythological theme is the Aeneas and Dido sarcophagus in the Museo Nazionale Romano, ASR XII,1, no. 68.

96 ASR XII,1, 179-87 (Grassinger). 
draw attention to them. The early examples of the type do not seem to have portrait features, though one early-third-century sarcophagus in the Palazzo Borghese has unfinished heads. ${ }^{97}$ From around 220 until 250, though, portrait heads become standard for this type. ${ }^{98}$ While both husband and wife were celebrated in these sarcophagi, the type seems to stress the love and virtue of the man rather than that of the woman. ${ }^{99}$ Through his assimilation to the martial hero Achilles he is shown as a warrior, while his love and support for his wife are expressed through his embrace of her slumped body. ${ }^{100}$ What it meant for a wife to be likened to Penthesilea is less clear; perhaps it is primarily the fact of her death which is important here rather than any specific virtues which she is seen to embody.

Masculine virtues: courage, heroism and marital devotion

The Achilles and Penthesilea sarcophagi offer two sorts of messages. Like the chests celebrating Endymion and Selene and Mars and Rhea Silvia they use portrait heads to allude to the happy union between husband and wife. At the same time the presentation of this couple on a battlefield also stresses the martial vigour of the man. The rise of this group of sarcophagi coincides with changes in the closely related group of battle sarcophagi, as well as with the new development of hunt sarcophagi. While both of these groups are usually discussed separately from the mythological sarcophagi, they actually share a number of similarities with them in their use of portraits to project the deceased into the midst of narratives of courage and heroism.

The battle sarcophagi form a small group which developed from around $160 / 170$ and have often been associated with the contemporary wars against the Sarmatians and Marcomanni. ${ }^{101}$ The earliest sarcophagi show a series of separate combats against Gallic opponents, but around 190 the depictions change to focus instead on one huge battle showing Roman soldiers attacking barbarians, with a focus on a central group of a mounted general. This development from

97 ASR XII,1, 119.

98 There are five sarcophagi where portraits are present (ASR XII,1, nos.125 (much restored), 127, 131, 137, 138) and four where the portraits seem to have been left unfinished (ASR XII,1, nos. 119, 130 (the current portraits are restorations, probably from unfinished bosses), 140, 141). These include sarcophagi from Campanian workshops in addition to Roman ones.

99 Fittschen 1984, 143-49, 160, n. 52 argues that a sarcophagus in the Vatican Belvedere has portraits of different dates, perhaps showing a man and his mother, but this dating is rejected by Grassinger, ASR XII,1, no. 127 in favour of one for both portraits in the 230 s.

100 ASR XII,1, no. 122 shows a general on a sella castrensis on the side, also stressing military virtues; Achilles is not given a portrait here.

101 Andreae 1956; Koch and Sichtermann 1982, 90-2. 
separate scenes of battle to a centralised group is closely parallel to the changes in Amazonomachy scenes, discussed above. Here, too, the central figure was increasingly identified with the deceased buried within through the addition of a portrait face. This remains unfinished on the late Antonine Portanaccio sarcophagi but is clearly visible on other examples of the type, most famously on the latest known example, the Great Ludovisi Sarcophagus in Rome. ${ }^{102}$ While the iconography of these sarcophagi has often been taken as evidence that they served as the tombs of men of senatorial rank, in many cases this cannot be proven. ${ }^{103}$ The addition of portraits serve to link the deceased with the courageous actions of a general, but the representations are heavily idealised, differing from the reality of a battlefield and strongly influenced by imperial iconography. ${ }^{104}$ Thus they can be read as imaginative versions of battle and military prowess into which the deceased is projected through the addition of his portrait features to the victorious general.

A similar trend can be seen on hunting sarcophagi. Until the late Severan period mythological hunt sarcophagi never receive portrait features, a surprising fact if portraits are thought simply to intensify the normative reading of mythological imagery on sarcophagi. We might have expected to find portraits in a range of mythological scenes which offered analogies for the virtues of the deceased buried within, such as those showing Hercules, Meleager or Adonis. Yet only a few of these show portraits. ${ }^{105}$ The Meleager sarcophagi are particularly striking. The story of Meleager and the Calydonian boar hunt is a popular theme on sarcophagi from the middle of the second century until well into the third century. However, only a very few third-century examples show portrait heads on the figure of Meleager. The earliest is a sarcophagus dated to the 220s or 230s. It shows Meleager on foot attacking the Calydonian boar and wearing the portrait features of a young man, similar to portraits of Alexander Severus. ${ }^{106}$ Another two examples come from later in the third century. ${ }^{107}$ All three overlap chronologically with the emergence of a new category of non-

102 Portonaccio: Rome, Museo Nazionale Romano inv. 112327; Giuliano 1979-1995 I, 8, 1: 177-88 (L. Musso). Great Ludovisi sarcophagus: Rome, Museo Nazionale Romano inv. 8574; Giuliano 1979-1995 I, 5: 56-67 (L. de Lachenal). For discussion of the type and particularly the unusual version in the Borghese collection see Schäfer 1979.

103 For the link with senatorial families see esp. Wrede 2001, 16, 21-4.

104 Schäfer 1979, 357.

105 Hercules: ASR III,1, no. 103 (Wrede 1981, no. 137, Jongste 1992, no. F6,); no. 107 (Wrede 1981, no. 136, Jongste 1992, no. F5); no. 110 (Jongste 1992, no. F9); all third century. On Adonis see below.

106 ASR XII,6, no. 26.

107 ASR XII,6, nos. 30, 152. Koch 1984, $27-9$ also notes the later addition of a portrait head to a reused Antonine Meleager sarcophagus. See also ASR XII,6, nos. 62, 74 for portraits on figures of children. 
mythological hunting sarcophagi where the protagonists regularly wear realistic portraits. ${ }^{108}$

B. Andreae's analysis of these hunt sarcophagi shows that they developed from the iconography of mythological hunt sarcophagi. The link is shown most clearly on the 'Lepri-Gallo' sarcophagus, dating probably to the $220 \mathrm{~s} .{ }^{109}$ This is a hybrid between a vita humana and mythological sarcophagus. The right half of the sarcophagus shows a hero on horseback hunting a boar, a scene taken from the iconography of Hippolytus sarcophagi. Unusually, the hero wears portrait features. ${ }^{110}$ To the left, however, the customary scene of his departure from Phaedra is replaced instead with a scene which shows the deceased man in human form. Instead of the dress of a mythological hero he wears the costume of a professional venator and is shown taking his leave from a female figure who also wears portrait features, presumably those of his wife. As Andreae noted, the iconography here is not taken from the departure scene on Hippolytus sarcophagi, which showed Hippolytus' rejection of Phaedra and her advances, but rather has parallels with the departure of Adonis from Aphrodite and with the representation of couples on marriage sarcophagi. ${ }^{111}$ Thus the tenderness and pathos of the man's departure from his wife is stressed.

The wife here appears in the guise of a female huntress, usually identified as the goddess Artemis/Diana, an appropriate patron goddess for the hunter. However, she also has similarities with the figures of Atalanta which appear on Meleager sarcophagi. The pose of the couple, especially the woman's gesture and the direction of her gaze, are closely paralleled on the central scene of a strigillated sarcophagus in Wilton House. ${ }^{112}$ This shows a naked hero making a sacrifice while a female huntress stands behind him touching his shoulder and looking towards him. The boar's head at his feet suggests that he is intended to represent Meleager, and that the woman is Atalanta. Both figures wear roughedout portrait faces, clear enough to see the impression of eyes, mouth and hair, but without a final finish. The suggestion seems to be that this is a couple who are assimilated in death to the lovers Meleager and Atalanta.

On the hunt sarcophagi the mounted hunter is the central figure, his active pose stressing his courage and victory. His face usually wears portrait features or is roughed out to receive them. Yet on a number of sarcophagi the addition of portrait features to one of the female figures in the scene also indicates the moral support which he receives from his wife. A few of these figures are dressed as

108 ASR I,2 (Andreae) gives a full analysis. See further below.

109 ASR III,2, 218-19, no. 179; Andreae ASR I,2, 18-21.

110 Hippolytus sarcophagi rarely show portraits, for one later example on the figure of Hippolytus in the hunt, see ASR III,2, 205-6, no. 165.

111 ASR I,2, 19.

112 ASR XII,6, no. 147 , mid-third-century. 
huntresses and identified as the goddess Artemis/Diana, as on the Lepri-Gallo sarcophagus and a chest in Barcelona. ${ }^{113}$ More commonly, though, the figure wears a helmet and carries a shield and is interpreted as a personification of Virtus. ${ }^{114}$ She is shown playing an active role in the hunt, offering support to the male hunter.

As we have seen, the messages of love, marital support and male courage which these sarcophagi express are also shared by some of the mythological sarcophagi. Both use portraits to draw out particular messages and values from the representations of idealised hunts and battles. While scholarship tends to treat these groups of sarcophagi separately, dividing them into 'mythological' and 'real life', the hunt sarcophagi discussed by Andreae are by no means realistic depictions of everyday life. The victim here is usually a lion, the hunting of which was reserved for emperors or shows in the amphitheatre, while the presence of symbolic figures such as that of Virtus also elevates the tone. This is a heroic and aspirational realm, presenting the deceased as a victor and celebrating his courage, prowess and vitality, perhaps even likening him to famous figures of the past, such as Alexander the Great. The sarcophagus asserts that the deceased was the sort of man to do great deeds but does not actually recount the real details of his history. Where Virtus wears portrait features the sarcophagus also shows us the support this man had from a wife who was always behind him or at his side, offering support.

Andreae suggests that the move away from mythological hunt sarcophagi allows for a change in the emphasis of the myth - whereas the great heroes Meleager, Adonis and Hippolytus all met early deaths despite their greatness, and thus could have acted as consoling examples to the bereaved, these instead assert the focus on victory and strength. Andreae sees this victory as one over death itself, here embodied by the lion. ${ }^{115}$ Whether such a strong message of apotheosis was intended remains, I think, debateable. Yet these sarcophagi certainly do assert powerful messages about what the deceased was like. The imagery chosen, while not drawn from the canonical stories of classical mythology, was just as 'mythologising' as those, in the sense that it asserts an aspirational and symbolic meaning rather than being a literal depiction. The few examples of portrait heads added to hunting figures on mythological scenes must be read alongside the non-mythological hunt sarcophagi; they suggest the

113 ASR I,2 21-24, no. 8 .

114 E.g. Andreae $A S R$ I,2 1980, 46-49, $157-8$, no.75 (in Reims, the portraits seem to have been added later); 57-59, no. 86 (Praetextatus catacombs); 43-45, 162-63, no. 104 (Capitoline Museum Rome, unfinished portrait on Virtus); 106, 171, no. 162 (Via de' Condotti, Rome, heads of both Virtus and hunter are unfinished); 66-68, 184-5, no. 247 (Vienna, heads of both Virtus and hunter roughed out but unfinished). See also Wrede 1981, 323-5, nos. 339-344.

115 ASR I,2, 134-6. 
desire here too to stress the positive side of the myth, asserting the hero's (and this deceased's) victory and prowess, rather than drawing attention to the death awaiting him. ${ }^{116}$ On both mythological and non-mythological battle and hunt sarcophagi the presence of portraits serves to parachute the deceased into an idealised realm, endowing his achievements with a glow of heroic endeavour.

The precise placement of the portraits can also be used to particularise the message. Only a few Hippolytus sarcophagi show portrait features. One of these, a sarcophagus in Capua, shows Hippolytus in the hunt scene with a portrait, the sarcophagus drawing attention to the deceased's courage. ${ }^{117}$ In others, however, the provision for portrait features suggests a different emphasis on the myth's significance. A sarcophagus in the Villa Doria Pamphili shows the usual depiction of the Hippolytus myth, with Hippolytus in the hunt to the right and his departure from Phaedra to the left. Hippolytus' head in the departure scene appears to have been left unfinished, but with the outlines of a portrait roughed out. ${ }^{118}$ The identification which is suggested with the deceased thus draws our attention to the departure of the hero, rather than to his prowess in hunting. The stress on departure is particularly clear on another, well-known sarcophagus in the Museo Nazionale Romano which changes the usual Hippolytus iconography to focus, instead, on the departure of the youth. ${ }^{119}$ The scene combines the departure of Hippolytus from Phaedra with a scene of the news of his death being brought to Theseus at the right hand end. Changes are made to the usual depiction: roughed-out portraits are given to the figures of Phaedra and Hippolytus and the young hero stands prominently in the centre of the relief, holding a diptych. The events of the mythological narrative are thrust into the background as the image stresses instead a mother's sorrow at the loss of a youth full of such potential. ${ }^{120}$

We might argue that the mythological content of this sarcophagus has been entirely ousted by its use as a message about parental love and loss. Yet the mythological subject is still present and presumably important. Rather than seeing this as an example of Entmythologierung ('demythologisation'), I would instead argue that the portraits and other iconographical changes direct the viewer to a particular interpretation of the myth, one which asserts that the young man buried here was as youthful, beautiful, educated and skilled in

116 They are especially close to the small group of boar-hunt sarcophagi, discussed by Andreae ASR I,2, 108-110.

117 ASR III,2, no. 165.

118 ASR III,2, no.166; Sichtermann and Koch 1975, 35, no. 28. The crucial central section of the sarcophagus is now missing but from old photographs it looks as though the head was at least roughed out. See also Calza 1977, 154-5, no. 182; pls. 114a and b show the former and current state of the sarcophagus.

119 MNR inv. 112444.

120 Zanker 1999; also Zanker and Ewald 2004, 328-9, no. 17. 
hunting as Hippolytus. Like that hero he met an early death, and was mourned by his parents just as extensively as Hippolytus was by Theseus. The addition of a sketched-out portrait to Phaedra might suggest that the woman shown here is also dead, perhaps even that it was her grief for her lost son which led to her death, just as Phaedra's grief over her love for Hippolytus led ultimately to hers. The particulars of the myth - that Phaedra's was an unholy, incestuous love, and that she committed suicide after contriving her step-son's death - are irrelevant; what matters is the depths of emotion the tale evokes, and its ability to show how great a loss has been endured.

\section{Portraits of Persephone - reading against the grain}

So far we have looked at a number of sarcophagi which feature portraits or unfinished heads. These could work in one of a number of ways. At the most prosaic level they help to draw out an aspect of the scene which might otherwise be lost, as on the figures of Ariadne on the Dionysiac sarcophagi in Bolsena and Oslo. In some cases they seem to have intensified a 'normal' reading of the scene, as for example on sarcophagi with Achilles and Penthesilea where portrait heads are the norm and presumably reflect the great love between the couple represented. On others, such as the Ariadne, Endymion and Rhea Silvia sarcophagi, they could perhaps help to stress one particular aspect of the myth the hoped-for happy sleep of the deceased in the Dionysiac realm, where Ariadne alone is given portrait features, or the love between the deceased couple, on sarcophagi where both Selene and Endymion are given portraits. On others, as we have seen above, the addition of portraits could help to direct our attention to one particular part of a myth. When portraits were given to the hero in the hunt scene they suggest the deceased's heroism, comparable to that of Meleager or Hippolytus. However, if portraits were intended for the hero in the departure scene the stress changes to focus on the grief of the bereaved at the loss of the deceased. The atypical addition of portrait features to figures on Persephone sarcophagi similarly shows their ability to draw out less prominent features of the myth and redirect the funerary message.

The rape of Persephone is one of the most popular images in funerary art. Appearing as far back as the fourth century BC Macedonian tombs at Vergina, in Roman art it appears not just on sarcophagi but also in mosaics and paintings which adorned tombs. ${ }^{121}$ It even appears on funerary urns and altars, which otherwise generally avoid mythological scenes. ${ }^{122}$ Yet it is largely lacking in domestic art. While other myths appear in a variety of contexts, this one had a

121 Lindner 1984.

122 Davies 1986; Sinn 1987, 80-81; Boschung 1987, 51-2. 
predominantly funereal tone. This is not surprising; the abrupt hastening down to the underworld of a beautiful maiden in the prime of life was an obvious metaphor for the pain and violence of untimely death. That the myth was commonly understood in such a way can be seen from a few scattered inscriptions. The reliefs of the Flavian Tomb of the Haterii included a fragmentary representation of the Rape of Persephone. A separate inscription identifying the daughters of the houses, Hateria Magna and Hateria Quintilla, as 'virgines raptae' suggests that the myth provided an analogy for their untimely deaths, the marriage with Death perhaps taking the place of a mortal marriage. ${ }^{123}$ A similar linkage appears later in the fourth-century Tomb of Vibia on the Via Appia where a painting of the rape is accompanied by an inscription reading 'Abreptio Vibies et discensio', 'the snatching and going down [to Hades] of Vibia. ${ }^{124}$ Yet the myth could be used to express the violence of the death of any person, not just young girls. Some of the funerary urns with representations of the myth do commemorate women, such as that for Saenia Longina. ${ }^{125}$ However, others could commemorate couples, men or male children. ${ }^{126}$ Even when these ash chests and altars commemorate women, they never make the link between Persephone and the deceased explicit through the use of portrait heads.

This flexibility of the myth as a metaphor for untimely death probably determined its use on sarcophagi where it is one of the most popular mythological themes, surviving in around 90 examples dating from the earliest sarcophagi well into the third century. Only a few of these, however, show portrait faces. On two sarcophagi the addition of portraits is found in the flower-picking scene and serves to redirect the emphasis of the scene. Both are quite heavily worn and dating is difficult. A sarcophagus in Messina shows the abduction of Persephone by Hades at the right, and Demeter on her serpent chariot at the left. ${ }^{127}$ In between we see Persephone kneeling in a meadow as Hades approaches her (Figure 6.10). Her face is worn but it clearly shows a Severan hairstyle with central parting and exposed ears. Such styles were worn in the mid Severan period, for example by the wives of Elagabalus, and continued in fashion until the 240s. The hair here does not appear to be tightly waved and is quite similar to a head in Copenhagen, identified as that of Julia Mamaea and dated to c. $230 .{ }^{128}$ The face of Persephone in the chariot scene is lost, but from

123 Wrede 1978, 425-8; idem 1981, 298, no. 272.

124 Lindner 1984, 59-60, no. 53; Wrede 1981, 300, no. 276.

125 Sinn 1987, no. 668; CIL VI.2570

126 Boschung 1987, nos. 821, 780, 781, 820; Wrede 1981, no. 16.

127 ASR III,3, no. 399; Mastelloni 1992, 75-9, no. 3.

128 Ny Carlsberg Glyptotek inv. 1416; Johansen 1995, 66-7, no. 23. Wrede 1981, 296-7, no. 266 dates the sarcophagus to $210-220$; Koch and Sichtermann 1982, 177 to $230-$ 240 ; Lindner $1984,68-9$, no. 78 to $225-250$. 


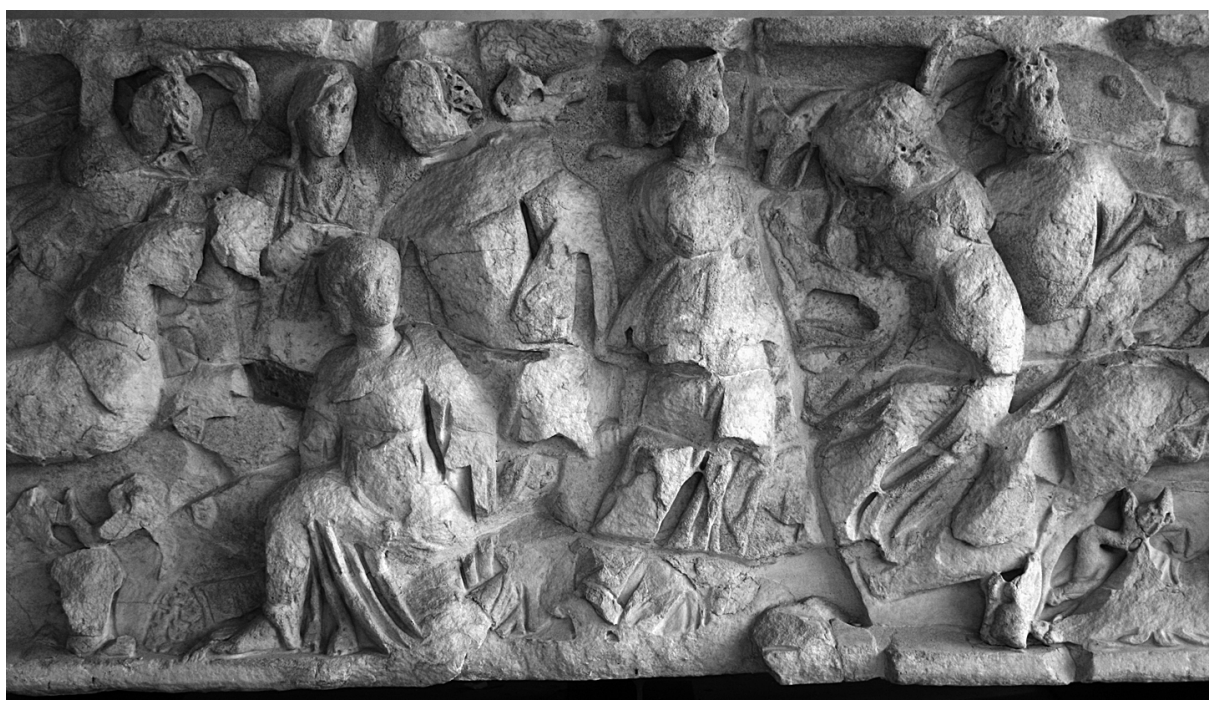

Figure 6.10: Persephone Sarcophagus, Messina; detail. Photograph: author.

the flowing locks which survive it seems clear that she did not have a portrait face; neither does Hades in either of his appearances. Rather than drawing a link between the death of the woman buried here and the violent untimely abduction of Persephone, the addition of portrait features instead draws our attention to the meeting between Persephone and Hades in the meadow. Venus leans towards Hades conspiratorially, as if drawing his attention to the girl. Persephone's dress slips from her right shoulder, a hint of her sexual attractiveness. The addition of portrait features to this scene draws attention to the beauty and attractiveness of Persephone and the deceased who is assimilated to her.

Another sarcophagus in the Palazzo Giustiniani in Rome also adds portrait features to the myth of Persephone (Figure 6.11). ${ }^{129}$ In the flower-picking scene Hades is given the features of a bearded, short-haired man, similar in style to many portrait heads of the mid third century. ${ }^{130}$ The face of Persephone here is very damaged but examination of the sarcophagus suggests that it too had a portrait face, though the hairstyle is simpler than the usual Severan styles. The hair is drawn back from the face in separate strands, as on the other figure of Persephone in the abduction scene. The incisions for the corners of the eyes can be clearly seen, showing that the face was not left unfinished, as had been

129 ASR III,3, no. 390.

130 Wrede 1981, 296, no. 265 dates it to c. 240; Koch and Sichtermann 1982, 177 to $230-$ 240. 


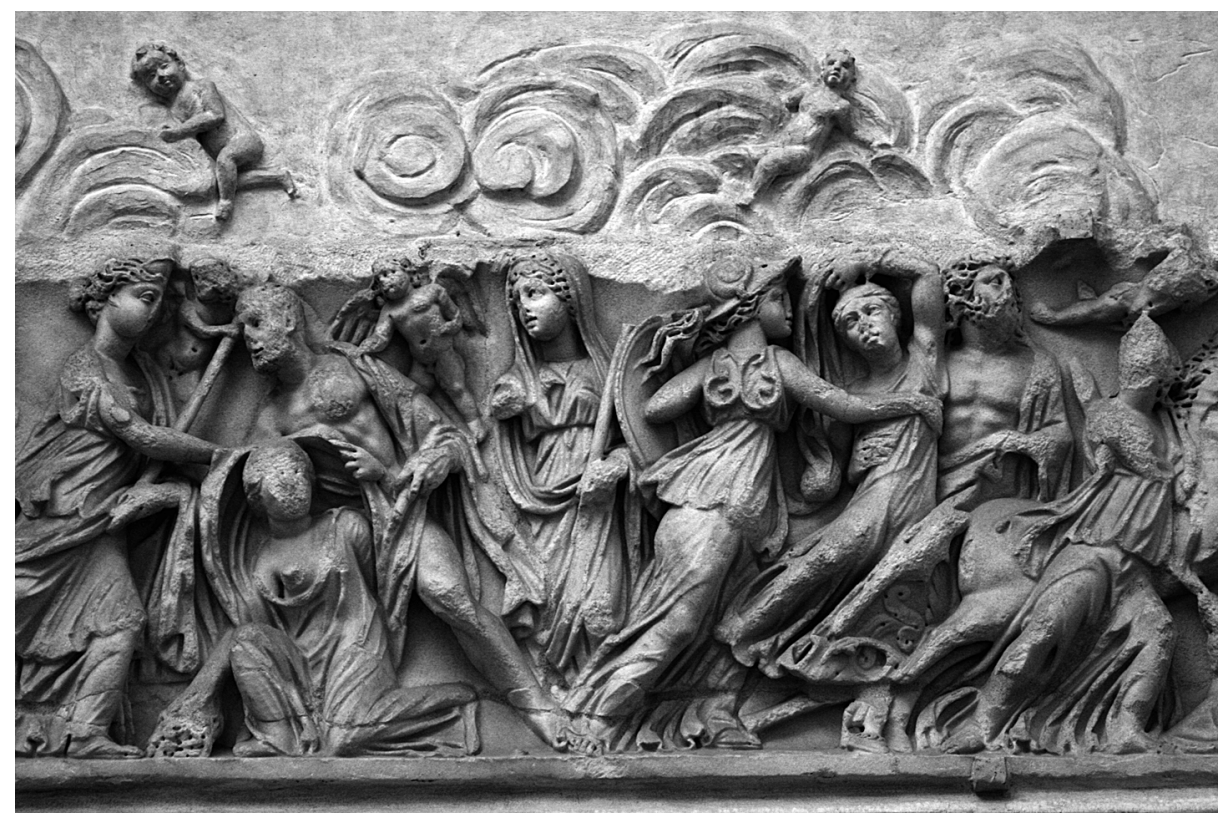

Figure 6.11: Persephone Sarcophagus, Palazzo Giustiniani, Rome. Photograph: author.

claimed by Robert. ${ }^{131}$ The face of Persephone in the abduction scene is also clearly characterised as a portrait by the careful chiselling of the hair, in contrast to the roughly drilled locks which appear on other figures. Here, however, Hades appears without a portrait face.

The addition of portrait features alters the usual focus of the myth. As in the Messina sarcophagus the attraction felt by Hades for Persephone is stressed in the flower-picking scene, where the figure of Venus rushes forwards to unveil the girl. Her sexual attractiveness is also highlighted by the slipping drapery on her right shoulder. The addition of portrait features serves to underline the beauty of the deceased woman, and the sexual union between her and her husband. In the abduction scene she looks back as she is torn away, perhaps an indication of the grief which her death evokes and her unwillingness to leave mortal life.

The use of portraits on these two sarcophagi suggests a widening of the messages of the myth, which is partly achieved by the inclusion of the flowerpicking scene, not always shown on sarcophagi. ${ }^{132}$ Persephone's beauty and desirability are stressed, while the equation of Hades with her husband on the Palazzo Giustiniani sarcophagus adds an additional layer of meaning, prompting

131 ASR III,3, 475; also Wrede 1981, 296, no. 265. Contra see also Zanker and Ewald 2004, 94.

132 See Koch and Sichtermann 1982, 175-9 on the development of the type. 
us to think about the deceased's life and marriage, and not just the fact of her death. On a third sarcophagus the addition of a portrait head gives a surprisingly positive spin to the myth. This is the famous chest in the Capitoline Museum. ${ }^{133}$ Here the other elements of the myth are pushed to the sides to allow the central space to be dominated by the representation of Persephone in Hades' chariot. Rather than appearing as a prone figure slumped in his arms, she is shown as if seated upright. Her upper torso is completely naked, stressing her beauty, and she is given portrait features. She looks steadily to the right, in the direction of travel. The overwhelming impression here is of a welcoming of death, an anticipation of the Underworld she is being taken towards. Perhaps the deceased wishes to suggest that she had no fear of death, or that she was looking forward to being reunited with her loved ones in the afterlife.

In its confident, almost triumphal, tone this sarcophagus can be likened to one showing the myth of Adonis in the Vatican, the only example of this myth I have found where portrait features are present. ${ }^{134}$ The iconography of this sarcophagus also differs from other Adonis sarcophagi. Rather than showing the wounded Adonis lying in Aphrodite's arms at one end of the relief, here the couple are prominently seated in the centre of the relief. A servant cleaning Adonis' leg refers to the wound he sustained in the hunt, but his erect authoritative pose makes it appear of minor importance. Both Adonis and Aphrodite are given portrait features, probably those of a young married couple. She gazes lovingly towards him, while he looks out towards the viewer. The clear sense is one of triumph, reunification in death and even heroisation. These two sarcophagi are some of the clearest examples we have of a different attitude towards death, not as an object of fear, but approached with the firm confidence that life and love could continue even beyond the grave. ${ }^{135}$

All three of the Persephone sarcophagi mentioned above show that the addition of portrait features changes the normal reading of the myth, turning a consolation for untimely death into a message about the beauty of the deceased, or a positive message about the afterlife. There is one other sarcophagus, however, where the figure of the abducted Persephone is unusually given portrait features. This is a fragment which was previously in the Villa Gentili but has since disappeared, probably into a private collection. ${ }^{136}$ An old photograph shows that it portrayed Hades grasping the figure of Persephone on

133 ASR III,3, no. 392; Zanker and Ewald 2004, 93-4, fig. 77, 370-2, no. 33.

134 ASR XII,1, no. 65; discussed by Koortbojian 1995, 50-3; Zanker and Ewald 2004, 210 - 1, figs 189-90;290-2, no. 5. See also, however, the sarcophagus in Berlin which pairs scenes from a vita privata sarcophagus with Adonis hunting; ASR XII,1, no. 59; Brilliant 1992.

135 See Newby 2007, 245-7.

136 ASR III,3, no. 380. 
his chariot. ${ }^{137}$ She is show in the usual unwilling pose but, strikingly, has a hairstyle which identifies her face as being a portrait. Her hair seems to have been parted in the middle and lies low on her neck before being drawn up into a bun. Her ears are clearly visible. Similar portrait types appear on heads of Octacilia Severa, Tranquillina and Etruscilla in the 240s though it could also be earlier. ${ }^{138}$ The stress here is on Persephone's violent abduction to Hades and its identification with the fate of the deceased. If the sarcophagus does belong to the 240s it might explain the presence of portrait features here to stress what we have seen above was usually the normative reading of the myth. Against a backdrop where Persephone sarcophagi begin to have been used to stress other aspects of the myth (as in the three examples mentioned above) perhaps the client here wanted to reinforce their own, more negative, reading - that it was a harsh and violent death which had ripped their loved one out of the world of the living.

\section{Conclusions}

This analysis of a number of mythological sarcophagi suggests that the decision to add portrait features did not simply reflect a desire to intensify the evident message of the imagery. Rather, when a range of possibilities for interpretation existed it helped to privilege a particular reading, or even to give a new twist to the usual use. It could also help to draw attention to the central mythological figure when the composition threatened to become overrun by subsidiary figures. In many ways the portraits act as the visual equivalent to inscriptions, which are relatively rare on sarcophagi. They provide extra information and help to focus the message of the mythological imagery. Yet this concentration on the link between hero or heroine and the deceased does not necessarily limit the imagery of the sarcophagus to one message alone. While a particular aspect of the analogy is drawn out through the assimilation, the rest of the narrative context of the myth might still extend the message, provoking verbalised comparisons such as those we find in consolatory poetry. Portrait features also act in flexible ways, sometimes deviating away from the usual iconography of the myth. While the precise messages of many of these sarcophagi must remain obscure to us, they attest to the continued flexibility and multivalency of mythological imagery in the funerary sphere and its possibilities for the expression of human values, hopes and beliefs.

137 Koch 1976, 109-10, no. 24, fig. 24.

138 Wegner 1979, 51-62, 78-82. 


\section{Acknowledgements}

I would like to thank the following for their help during the preparation of this paper: Chris Gravett of Woburn Abbey for providing photographs; Maria Pia Malvezzi of the British School at Rome for arranging access to palazzi in Rome; the owners of the Palazzi Mattei and Giustiniani for allowing access to study and photograph the sarcophagi and Dott.ssa Maria Amalia Mastelloni for access to the Persephone sarcophagus in Messina. Other museums and organisations are credited in the list of figures. Initial research on this topic was carried out during a trip to Rome funded by a British Academy small grant. The research was completed and written up during a period of research leave funded by the University of Warwick and the AHRC Research Leave scheme. I am grateful to all these institutions for their support.

\section{Bibliography}

Andreae, B. Motivgeschichtliche Untersuchungen zu den römischen Schlachtsarkophagen (Berlin, 1956).

Andreae, B. Studien zur römischen Grabkunst (Heidelberg, 1963).

Andreae, B. Bossierte Porträts auf römischen Sarkophagen - ein ungelöstes Problem, in: B. Andreae (ed.), Symposium über die antiken Sarkophage, Pisa 5.-12. September 1982 (Marburger Winckelmann-Programm, 1984), 109-128.

Angelicoussis, E. The Woburn Abbey Collection of Classical Antiquities. Monumenta Artis Romanae XX (Mainz am Rhein, 1992).

Blome, P. Zur Umgestaltung griechische Mythen in der römischen Sepulkralkunst. Alkestis - Protesilaus- und Proserpinasarkophage. Mitteilungen des Deutschen Archäologischen Instituts, Römische Abteilung 85(1978), 435-457.

Blome, P. Funerärsymbolische Collagen auf mythologischen Sarkophagreliefs. Studi Italiani di Filologia Classica 10.2 (1992), 1061-1073.

Boschung, D. Antike Grabaltäre aus den Nekropolen Roms. Acta Bernensia 10 (Bern, 1987).

Brilliant, R. Roman Myth/Greek Myth: Reciprocity and Appropriation on a Roman Sarcophagus in Berlin, in: Studi Italiani di Filologia Classica 10.2 (1992), 10301045. Reprinted in: Commentaries on Roman Art: Selected Studies, edited by R. Brilliant (London, 1994), 423-438.

Calza, R. (ed.). Antichità di Villa Doria Pamphilj (Rome, 1977).

Cumont, F. Recherches sur le symbolisme funéraire des romains (Paris, 1942).

Davies, G. The rape of Proserpina on Roman grave altars and ash chests. Shadow 3.2 (1986), 51-60.

di Mino, M. R. and Bertinetti, M. (eds.). Archeologia a Roma. La material e la tecnica nell'arte antica (Rome, 1990).

Ewald, B. Death and Myth. New Books on Roman Sarcophagi. American Journal of Archaeology 103 (1999), 344-348.

Engemann, J. Untersuchungen zur Sepulkralsymbolik der späteren römischen Kaiserzeit (Jahrbuch für Antike und Christentum Ergänzungsband 2) (Münster, 1973). 
Fejfer, J. Roman portraits in context. (Berlin, 2008).

Fittschen, K. Zum Kleobis und Biton-Relief in Venedig. Jahrbuch des Deutschen Archäologischen Instituts 85 (1970), 171-193.

Fittschen, K. Die Bildnistypen der Faustina minor und die Fecunditas Augustae (Göttingen, 1982).

Fittschen, K. Über Sarkophage mit Porträts verschiedener Personen, in: B. Andreae (ed.), Symposium über die antiken Sarkophage, Pisa 5.-12. September 1982 (Marburger Winckelmann-Programm, 1984), 129-161.

Giuliano, A. Museo Nazionale Romano. Le Sculture. 12 vols (Rome, 1979-1995).

Grassinger, D. Mythen auf römischen Sarkophagen. Journal of Roman Archaeology 11 (1998), 554-556.

Guerrini, L. Palazzo Mattei di Giove. Le Antichità (Rome, 1982).

Huskinson, J. 'Unfinished Portrait heads' on later Roman sarcophagi: some new perspectives. Papers of the British School at Rome 66 (1998), 129-168.

Johansen, F. Roman Portraits III. Ny Carlsberg Glyptotek (Copenhagen, 1995).

Jongste, P. F. B. The Twelve Labours of Hercules on Roman Sarcophagi (Rome, 1992).

Koch, G. Verschollene mythologische Sarkophage. Ein archäologischer Steckbrief. Archäologischer Anzeiger 1976, 101-110.

Koch, G. and Sichtermann, H. Römische Sarkophage. Handbuch der Archäologie (Munich, 1982).

Koortbojian, M. Myth, Meaning and Memory on Roman Sarcophagi (Berkeley, Los Angeles and London, 1995).

L'Orange, H. P. Eros psychophoros et sarcophages romains. Institutum Romanum Norvegiae. Acta ad Archaeologiam et artium historiam pertinentia 1 (1962), 41-48.

Lattimore, R. Themes in Greek and Latin Epitaphs (Urbana, 1942).

Lindner, R. Der Raub der Persephone in der antiken Kunst (Würzburg, 1984).

Marrou, H.-I. MOY $I$ IKO $\Sigma$ ANHP. Étude sur les scènes de la vie intellectuelle figurant sur les monuments funéraires romains (Grenoble, 1938).

Mastelloni, M. A. Sarcofagi romani del Museo Regionale di Messina. Quaderni dell'attività didattica del Museo Regionale Messina 2 (1992), 57-91.

Matz, F. Stufen der Sepulkralsymbolik in der Kaiserzeit, in: Symposium über die antiken Sarkophagreliefs, edited by H. Wiegartz et al. Archäologischer Anzeiger 86 (1971), $86-122$ at $102-116$.

Meiggs, R. Roman Ostia (Oxford, 1973).

Moretti, M. Nuove scoperte e acquisizioni nell' Etruria Meridionale (Exhibition Catalogue, Villa Giulia). (Rome, 1975).

Mottahedeh, P. E. Review of Wrede 1981. American Journal of Archaeology 88 (1984), 95-96.

Mouritsen, H. Freedmen and Decurions: Epitaphs and Social History in Imperial Italy. Journal of Roman Studies 95 (2005), 38-63.

Müller, F. G. J. M. Iconological Studies in Roman Art I: The So-Called Peleus and Thetis Sarcophagus in the Villa Albani (Amsterdam, 1994).

Muth, S. Drei statt vier. Zur Deutung der Feldherrnsarkophage. Archäologischer Anzeiger (2004), 263-273.

Newby, Z. Art at the crossroads? Themes and style in Severan art, in: Severan Culture, edited by S. Swain, S. Harrison and J. Elsner (Cambridge, 2007), 201-249.

Nock, A. D. Sarcophagi and Symbolism. American Journal of Archaeology 50 (1946), $140-170$.

North, J. A. These he cannot take. Journal of Roman Studies 73 (1983), 169-174.

Peek, W. Griechische Vers-Inschriften (Berlin, 1955). 
Schäfer, T. Zum Schlachtsarkophag Borghese. Mélanges de l'École française de Rome, Antiquité 91 (1979), 355-382.

Schauenburg, K. Porträts auf römischen Sarkophagen, in: Eikones. Studien zum griechischen und römischen Bildnis. Hans Jucker zum sechzigsten Geburtstag gewidmet (Zwölftes Beiheft zur Halbjahresschrift Antike Kunst) (Bern, 1980), 153-159.

Sichtermann, H. Späte Endymion-Sarkophage. Methodisches zur Interpretation (BadenBaden, 1966).

Sichtermann, H and Koch, G. Griechische Mythen aufrömischen Sarkophagen (Tübingen, 1975).

Sinn, F. Stadtrömische Marmorurnen (Beiträge zur Erschließung hellenistischer und kaiserzeitlichen Skulptur und Architektur 8) (Mainz am Rhein, 1987).

Sperti, L. Rilievi Greci e Romani de Museo Archeologico di Venezia (Rome, 1988).

Turcan, R. Les sarcophages romains et le problème du symbolisme funéraire. Aufstieg und Niedergang des Römischen Welt 16.2 (1978), 1700-1735.

Vighi, R. Cesano di Roma. Rinvenimento di sarcofago romano e dei resti di una capella medioevale. Notizie degli scavi di antichità 1935, 244-247.

Walker, S. The sarcophagus of Maconiana Severiana, in: Roman Funerary Monuments in the J. Paul Getty Museum I. Occasional Papers on Antiquities 6 (Malibu, 1990), 8394.

Wegner, M. Das römische Herrscherbild III.3. Gordianus III bis Carinus (Berlin, 1979).

Whitehead, J. The 'Cena Trimalchionis' and biographical narration in Roman middleclass art, in: Narrative and Event in Ancient Art, edited by P. J. Holliday (Cambridge, 1993), 229-325.

Wiggers, H. B. and Wegner, M. Das Römische Herrscherbild III.1 (Berlin, 1971).

Wood, S. Alcestis on Roman Sarcophagi. America Journal of Archaeology 82 (1978), 499-510. Reprinted with postscript in: Roman Art in Context. An Anthology, edited by E. D’Ambra (New Jersey, 1993), 84-103.

Wrede, H. Die Ausstattung stadrömische Grabtempel und der Übergang zur Körperbestatung. Mitteilungen des Deutschen Archäologischen Instituts, Römische Abteilung 85 (1978), 411-433.

Wrede, H. Consecration in Formam Deorum: Vergöttlichen Privatpersonen in der römischen Kaiserzeit (Mainz, 1981).

Wrede, H. Senatorische Sarkophage Roms. Der Beitrag des Senatorienstandes zur römischen Kunst der hohen und späten Kaiserzeit. Monumenta Artis Romanae 29 (Mainz am Rhein, 2001).

Zanker, P. and Ewald, B. C. Mit Mythen leben. Die Bilderwelt der römischen Sarkophage (Munich, 2004).

Zanker, P. Phädras Trauer und Hippolytos' Bildung: zu einem Sarkophag im Thermenmuseum, in: Im Spiegel des Mythos. Bilderwelt und Lebenswelt. Palilia 6, edited by F. de Angelis and S. Muth (Wiesbaden, 1999), 131-142. 
